\title{
C14 Laves Phase Metal Hydride Alloys for Ni/MH Batteries Applications
}

\author{
Kwo-Hsiung Young ${ }^{1,2, *} \mathbb{C}$, Shiuan Chang ${ }^{2,3}$ and Xinting Lin 4 \\ 1 Department of Chemical Engineering and Materials Science, Wayne State University, Detroit, MI 48202, USA \\ 2 BASF/Battery Materials_Ovonic, 2983 Waterview Drive, Rochester Hills, MI 48309, USA; \\ ShiuanC@wayne.edu \\ 3 Department of Mechanical Engineering, Wayne State University, Detroit, MI 48202, USA \\ 4 Department of Chemical Engineering and Materials Science, Michigan State University, East Lansing, \\ MI 48824, USA; linxinti@msu.edu \\ * Correspondence: kwo.young@basf.com; Tel.: +1-248-293-7000
}

Received: 6 June 2017; Accepted: 18 August 2017; Published: 14 September 2017

\begin{abstract}
C14 Laves phase alloys play a significant role in improving the performance of nickel/metal hydride batteries, which currently dominate the $1.2 \mathrm{~V}$ consumer-type rechargeable battery market and those for hybrid electric vehicles. In the current study, the properties of C14 Laves phase based metal hydride alloys are reviewed in relation to their electrochemical applications. Various preparation methods and failure mechanisms of the C14 Laves phase based metal hydride alloys, and the influence of all elements on the electrochemical performance, are discussed. The contributions of some commonly used constituting elements are compared to performance requirements. The importance of stoichiometry and its impact on electrochemical properties is also included. At the end, a discussion section addresses historical hurdles, previous trials, and future directions for implementing C14 Laves phase based metal hydride alloys in commercial nickel/metal hydride batteries.
\end{abstract}

Keywords: metal hydride; nickel metal hydride battery; Laves phase alloy; rare earth element; electrochemistry; pressure concentration isotherm

\section{Introduction}

Nickel/metal hydride $(\mathrm{Ni} / \mathrm{MH})$ batteries have a wide range of applications including portable consumer electronics [1], transportation [2], and stationary power sources [3,4] as it features benefits such as safe chemistry, sustainable life, a stable raw material supply, high performance, and reasonable cost [5]. The most common metal hydride ( $\mathrm{MH}$ ) alloy used as the active material in negative electrode of $\mathrm{Ni} / \mathrm{MH}$ batteries is a misch-metal (combination of $\mathrm{La}, \mathrm{Ce}, \mathrm{Pr}$, and $\mathrm{Nd}$ ) based $\mathrm{AB}_{5}$ alloy with a $\mathrm{CaCu}_{5}$ crystal structure. Recently, a misch-metal and $\mathrm{Mg}$ in the superlattice alloy $\left(\mathrm{A}_{2} \mathrm{~B}_{7}\right.$ type) with its corresponding improvement in the gravimetric energy density has become more popular in consumer and stationary applications [5-9]. Meanwhile, the Laves phase $\mathrm{AB}_{2} \mathrm{MH}$ alloy has also been proposed to improve the energy density of $\mathrm{Ni} / \mathrm{MH}$ batteries. Although the $\mathrm{AB}_{2} \mathrm{MH}$ alloy has the potential for relatively high capacity potential $\left(440 \mathrm{mAh} \cdot \mathrm{g}^{-1}[10,11]\right.$ when compared to $330 \mathrm{mAh} \cdot \mathrm{g}^{-1}$ from the $\mathrm{AB}_{5}$ alloy), it suffers from a relatively slow electrochemical reaction rate and a less-desirable cycle life (see comparison in Table 1) [12]. A further comparison of the main battery performances between $\mathrm{AB}_{2}$ and $A_{5} M H$ alloys can be found in previous research (Table 1 in [13]). Numerous papers, including a few reviews [14-20], have been have examined how to improve the electrochemical properties of $\mathrm{AB}_{2} \mathrm{MH}$ alloys, however, an updated comprehensive review of this subject would be of use. The current work details the alloy preparation methods, performance requirements, failure mechanisms, constituent phases, selection of elements and stoichiometry, as well as the historical challenges and directions for future research. 
Table 1. The performance comparison of hydrogen-absorbing alloys with different chemistries [12]. The numbers in parentheses are the nominal B/A ratios. The symbols are ++ (superb), + (good), 0 (acceptable), and - (poor).

\begin{tabular}{cccccc}
\hline Properties & $\mathbf{A B}_{2}$ (2) & $\mathbf{A B}_{3}$ (3) & $\mathbf{A}_{\mathbf{2}} \mathbf{B}_{7}$ (3.5) & $\mathbf{A}_{5} \mathbf{B}_{19}$ (3.8) & $\mathbf{A B}_{5}$ (5) \\
\hline $\mathbf{A B}_{2}$ number of units & 1 & 1 & 1 & 1 & 0 \\
$\mathbf{A B}_{5}$ number of units & 0 & 1 & 2 & 3 & 1 \\
Electrochemical capacity/weight & ++ & 0 & + & 0 & - \\
Electrochemical capacity/volume & 0 & 0 & + & 0 & - \\
Pulverization of alloy, oxidation (corrosion) & + & + & + & - & - \\
Reversibility of hydrogen absorption/release & - & 0 & + & $0 \sim+$ & ++ \\
Battery Life & - & 0 & ++ & 0 & + \\
\hline
\end{tabular}

$\mathrm{C} 14, \mathrm{C} 15$, and $\mathrm{C} 36$ Laves phases are composed of the same $\mathrm{A}_{2} \mathrm{~B}_{4}$ unit-block, but with different stacking sequences; $\mathrm{C} 14$ has an $a-b-a-b$ stacking sequence, which leads to a hexagonal structure (Figure 1a); C15 has an $a-b-c-a-b-c$ stacking and a cubic structure (Figure 1b); and C36 exhibits $a-b-a-c$ stacking and a rhombohedral (dihexagonal) structure (Figure 1c) [21-23]. The C14 and C15 phases are more commonly observed in $\mathrm{MH}$ alloys, whereas the C36 phase may exist between the $\mathrm{C} 14$ and C15 phases [24] but is difficult to identify using X-ray diffraction (XRD) [25,26]. Alloys with both C14 and C15 crystal structures serve as hydrogen-storage (H-storage) alloys and electrode materials. $\mathrm{C} 15$ alloys have better high-rate and low-temperature performance, however the C14 alloys were more widely used earlier when alloy composition design was driven by capacity and cycle stability. $\mathrm{An} \mathrm{AB}_{2} \mathrm{MH}$ alloy with a C14-predominated structure was used in the first commercialized electric vehicle, EV1 by General Motor (Detroit, MI, USA). Similar alloys with the same structure were also used in the first-generation Ni/MH batteries made by Gold Peak Industries (Hong Kong, China) and Hitachi-Maxwell (Osaka, Japan). Recently, the electrochemical performances of a state-of-art C14-predominate $\mathrm{MH}$ alloy were compared to those from a recently proposed C15-based $\mathrm{MH}$ alloy together with a review of the development works done on the C15-based $\mathrm{MH}$ alloys [27]. In this paper, we will review only research focused on the C14-predominated $\mathrm{MH}$ alloys.

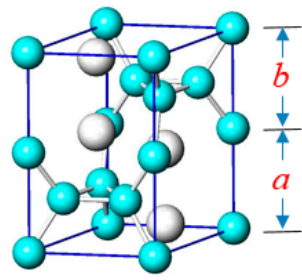

(a)

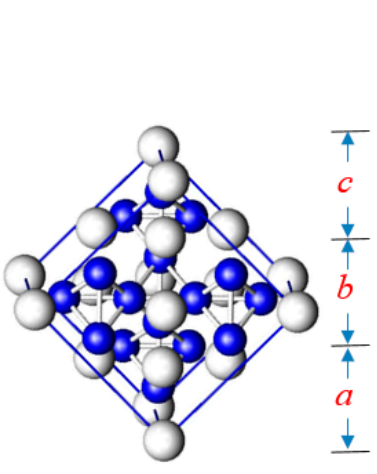

(b)

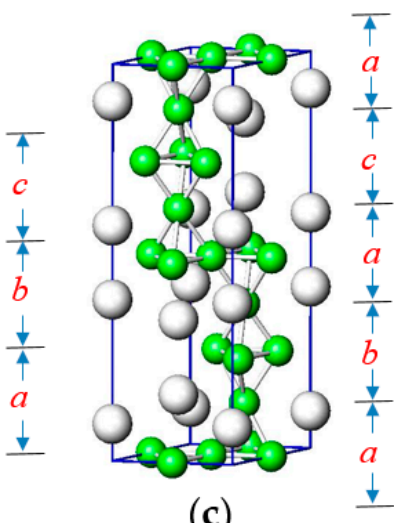

(c)

Figure 1. Schematic of (a) C14 (hexagonal), (b) C15 (cubic), (c) and C36 (rhombohedral) crystal structures [28].

\section{Alloys Preparation}

Conventionally, when used as the active material in negative electrodes of $\mathrm{Ni} / \mathrm{MH}$ batteries, the $\mathrm{MH}$ alloys are initially prepared by melting and casting. Then, an annealing process is applied to the ingot to improve compositional uniformity and to reduce internal stress. To reach a final particle size of less than 200 mesh $(75 \mu \mathrm{m})$, most ingots need to be crushed into powder through mechanical grinding or hydrogenation. The powder may require additional surface treatments to 
enhance its electrochemical properties. Negative electrode fabrication methods have been previously reviewed [13].

\subsection{Melting and Casting}

A few preparation methods for MH alloys are described in an introductory article [29] that covers conventional vacuum induction melting (VIM) [30], arc melting (AM) [31], centrifugal casting (CC), melt-spinning (MS) [32-34], gas atomization (GA) [35,36], and mechanical alloying (MA) [37-39]. A vacuum plasma spray (PS) has also been employed for research purposes [40]. While AM only produces small quantity of alloy ( 5 to $200 \mathrm{~g}$ ) for laboratory use, VIM can produce ingots ranging from $1 \mathrm{~kg}$ to 1 ton (Figure 2). In terms of electrochemical property, no distinct difference is observed between $\mathrm{AB}_{2} \mathrm{MH}$ alloys prepared by VIM and those prepared by AM [41], except for a slightly higher capacity obtained from VIM due to a larger sample/chamber ratio [42]. Samples from different locations of a VIM-process ingot may have different microstructures, but the electrochemical capacities are very similar. For example, the microstructures of different pieces of ingot prepared by a 60-kg VIM furnace are shown in Figure 3. According to the analytic results from x-ray diffraction (X'Pert Pro, Philips, Amsterdam, The Netherlands) and scanning electron microscope (SEM) (JEOL-JSM6320F, JEOL, Tokyo, Japan) with the x-ray energy dispersive spectroscopy capability, this alloy is C14-predominant with $\mathrm{C} 15, \mathrm{TiNi}$, and families of ( $\mathrm{Zr}, \mathrm{Ni})$ secondary phases. We obtained this composition by continuing optimization and testing more than 400 alloys. The properties of C14-predominated alloys prepared by VIM and other techniques were also previously compared [43] and are summarized in Table 2. Because of the small sample size, use of expensive argon gas, and high utility costs from water chiller and arc power supply, AM is the most expensive method for making MH alloys. Photographs of equipment and different pouring processes are shown in Figures 4 and 5, respectively. SEM surface morphology and cross-section micrographs of products are compared in Figures 6 and 7, respectively. A review of Japanese Patent Applications shows 9 different ingot preparation methods for $\mathrm{MH}$ alloys [44]. For $\mathrm{MH}$ alloys that are sensitive to oxygen contamination from the reduction of ceramic refractory used as furnace crucible, a skull VIM melting can be used (Figure 8). MA in a shaker mill or an attritor is a popular method for making meta-stable/amorphous alloys not allowed in the phase diagram [45] (Figure 9).

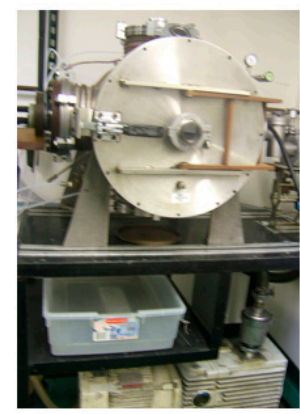

(a)

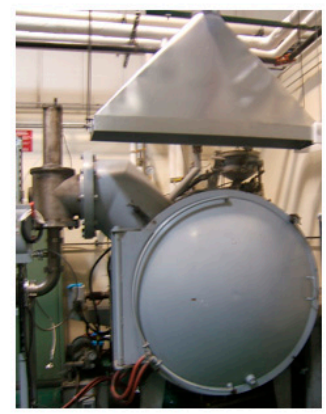

(b)

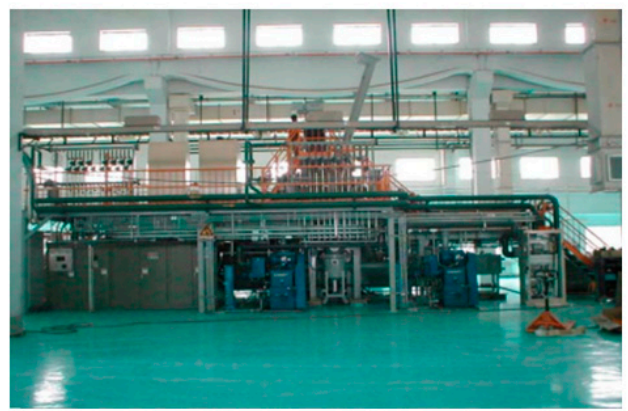

(c)

Figure 2. Images of (a) a $200 \mathrm{~g}$, (b) $60 \mathrm{~kg}$, and (c) 1 ton vacuum induction melting (VIM) furnaces. While the first two are currently installed in BASF-Ovonic, the third one is operated by Rare-earth Ovonic Metal Hydride Alloy Company in Baotou, Inner Mongolia, China. 


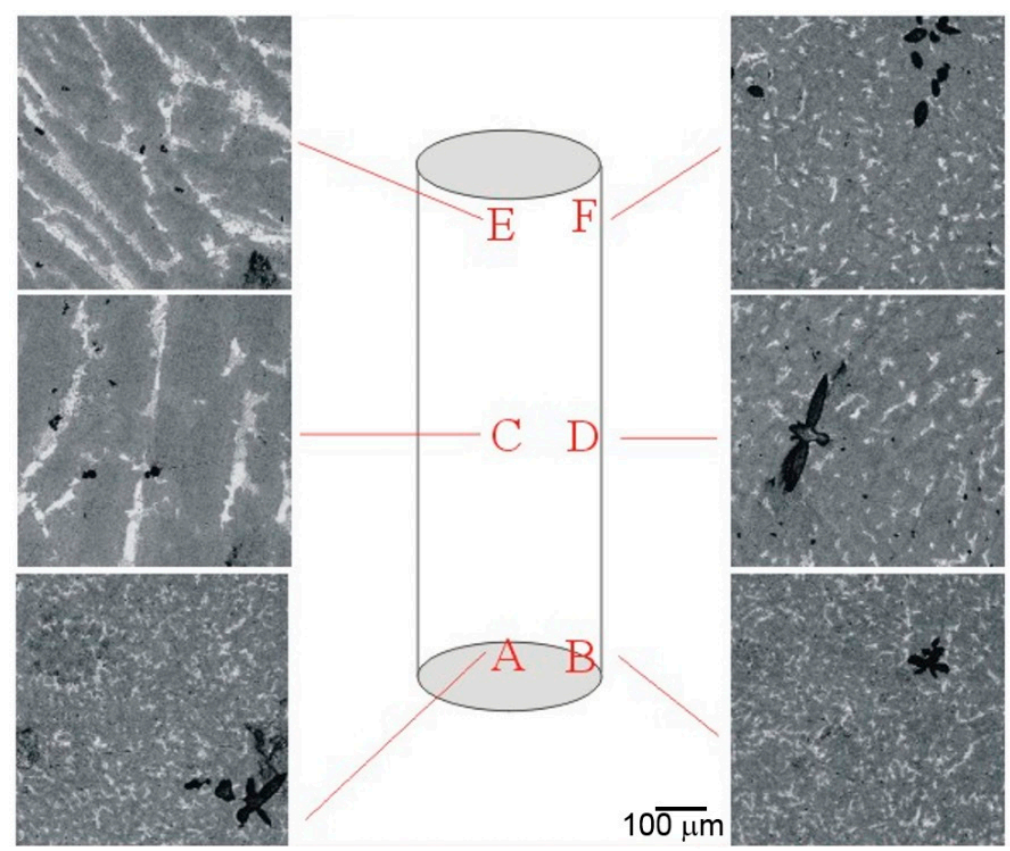

Figure 3. Scanning Electron Microscope (SEM) cross-section micrographs showing the microstructures from various locations of a 100-kg $\mathrm{AB}_{2}$ ingot with a composition of $\mathrm{Ti}_{9} \mathrm{Zr}_{26.2} \mathrm{~V}_{5} \mathrm{Cr}_{3.5} \mathrm{Mn}_{15.6}$ $\mathrm{Co}_{1.5} \mathrm{Ni}_{38} \mathrm{Sn}_{0.8} \mathrm{Al}_{0.4}$ prepared by VIM. The electrochemical discharge capacities of ingots from locations $\mathrm{A}, \mathrm{B}, \mathrm{C}, \mathrm{D}, \mathrm{E}$, and $\mathrm{F}$ are 390, 400, 391, 402, 389, and $397 \mathrm{mAh} \cdot \mathrm{g}^{-1}$ with a discharge current density of $8 \mathrm{~mA} \cdot \mathrm{g}^{-1}$. The dark, white, and gray regions are $\mathrm{ZrO}_{2}$ inclusions, secondary phases (TiNi, $\mathrm{ZrNi}$, $\mathrm{Zr}_{7} \mathrm{Ni}_{10}$, and $\mathrm{Zr}_{9} \mathrm{Ni}_{11}$ ), and main $\mathrm{C} 14$ phases, respectively.

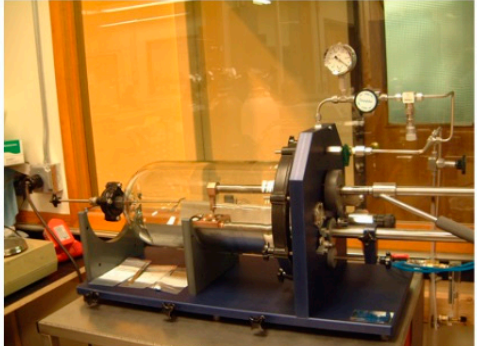

(a)

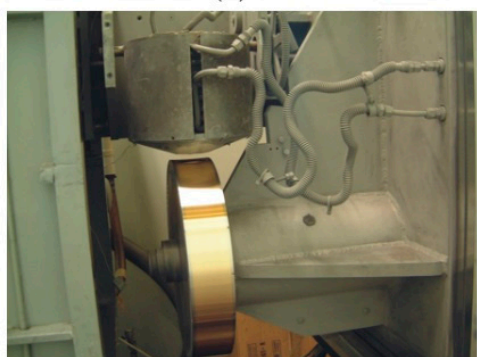

(c)

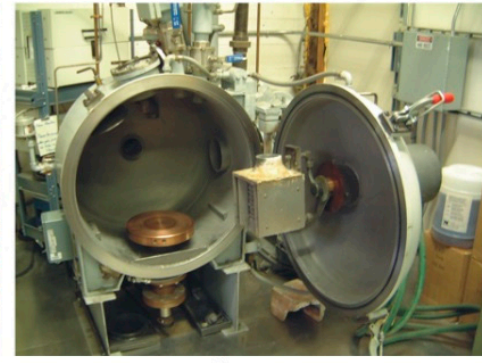

(b)

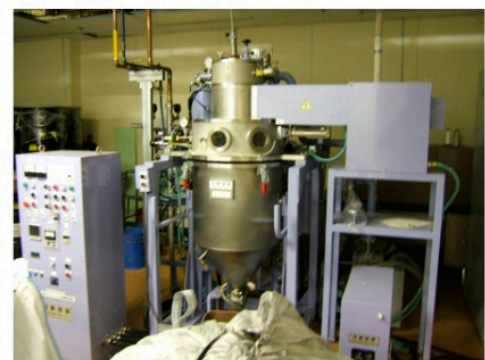

(d)

Figure 4. Images of (a) an arc melter, (b) a centrifugal casting VIM, (c) a melt-spinning VIM, and (d) a gas atomizer. The first three are operated in Ovonic-BASF and the fourth one is in Eutectix, Troy, MI, USA. 


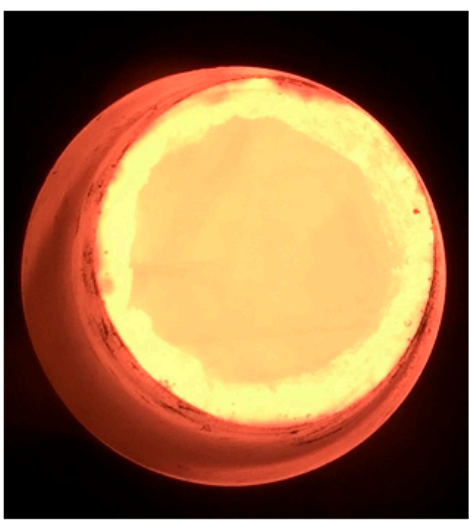

(a)

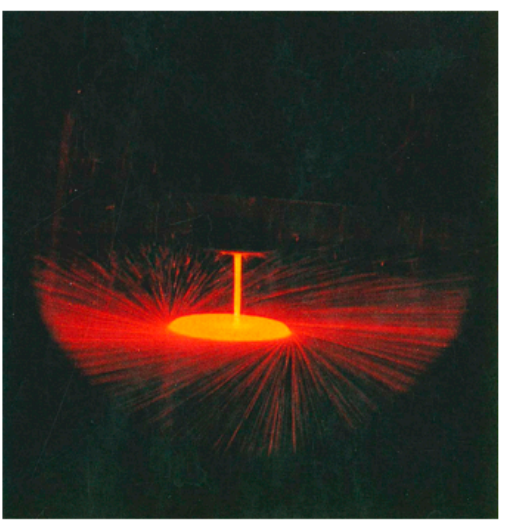

(b)

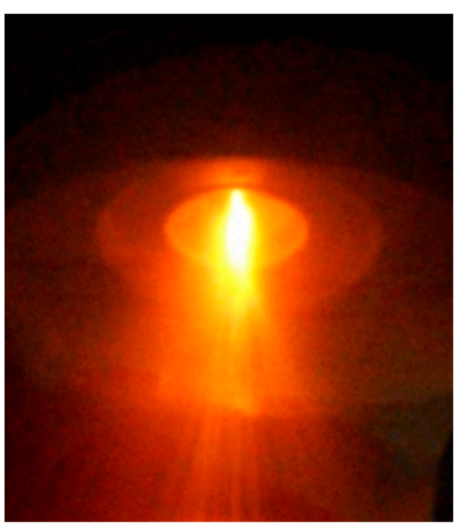

(c)

Figure 5. Images during operation of (a) a VIM, (b) a centrifugal casting (CC), (c) a gas atomization (GA) (Courtesy of Daido Steel, Nagoya, Japan).

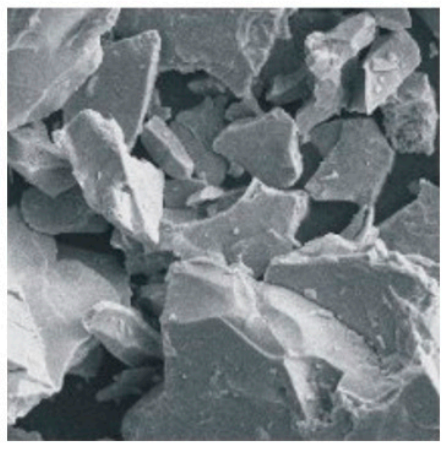

(a)

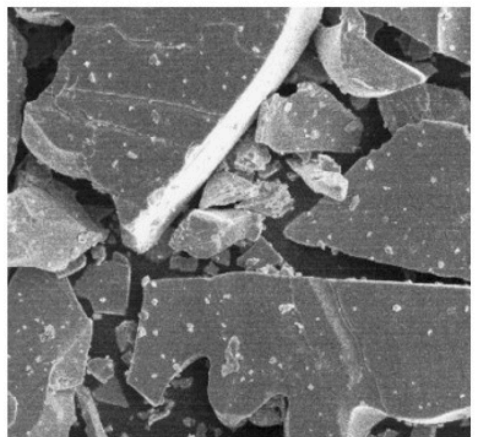

(b) $\overline{20 \mu \mathrm{m}}$

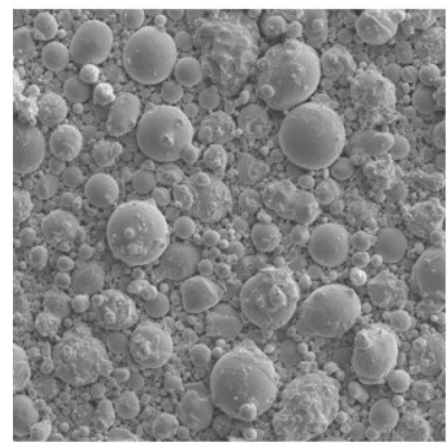

(c)

Figure 6. SEM micrographs showing top morphologies of alloys prepared by (a) VIM with a mechanical crush-and-grind, (b) melt-spinning (MS), and (c) GA processes.

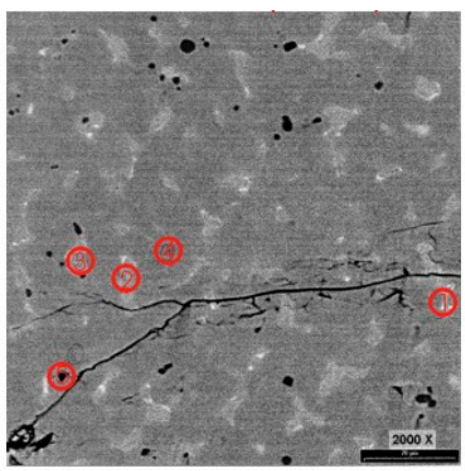

(a)

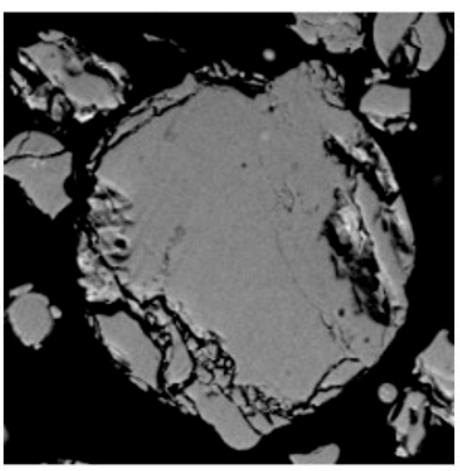

(b)

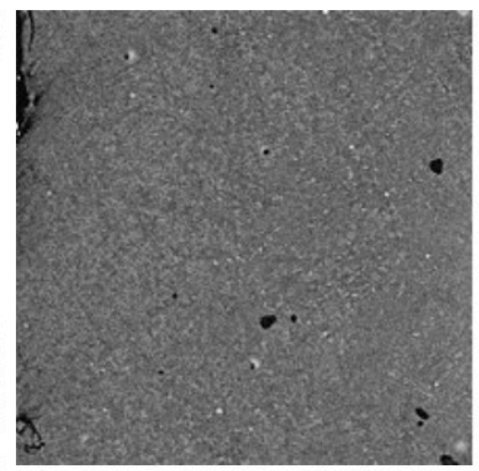

(c)

Figure 7. SEM cross-section micrographs from a C14-predominated alloy $\left(\mathrm{Ti}_{12} \mathrm{Zr}_{21.5} \mathrm{~V}_{10} \mathrm{Cr}_{8.5} \mathrm{Mn}_{13.6}\right.$ $\mathrm{Co}_{1.5} \mathrm{Ni}_{32.2} \mathrm{Sn}_{0.3} \mathrm{Al}_{0.4}$ ) prepared by (a) a conventional VIM, (b) GA, and (c) MS processes. Areas 1, 2, 3, 4, and 5 in (a) are $\mathrm{C} 14, \mathrm{C} 15$, TiNi, body-centered-cubic (bcc), and $\mathrm{ZrO}_{2}$ phases, respectively, as determined by their compositions and crystal structures. 


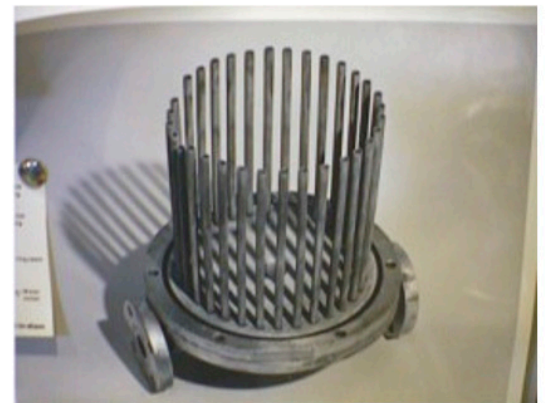

(a)

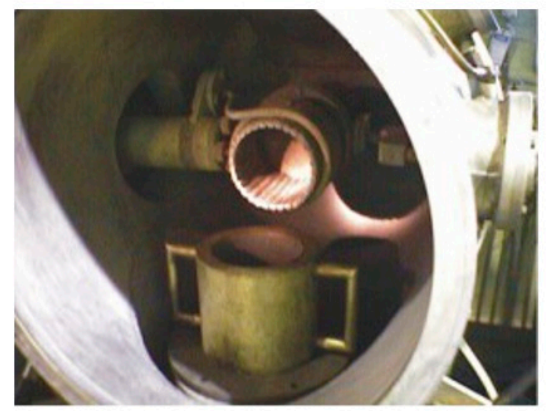

(c)

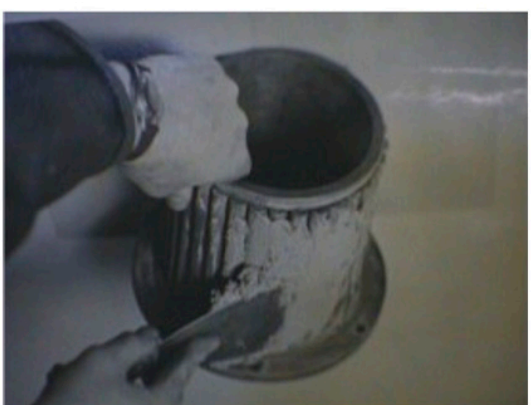

(b)

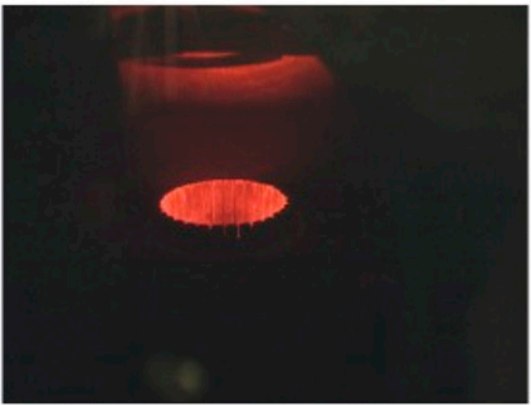

(d)

Figure 8. Images of skull melting: (a) water-cooling $\mathrm{Cu}$ rods, (b) application of refractory outside the crucible, (c) setup of a crucible and a mold in a vacuum chamber, and (d) during operation (Courtesy of Albany Research Center, Albany, OR, USA).

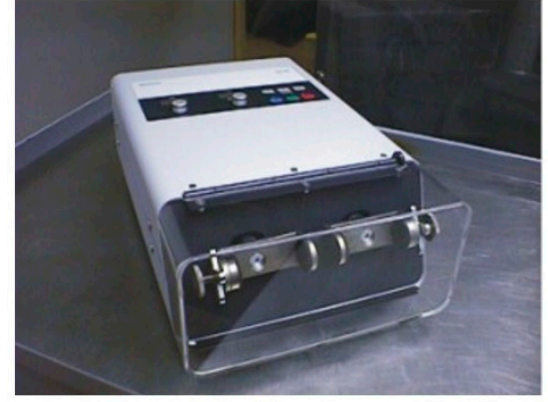

(a)

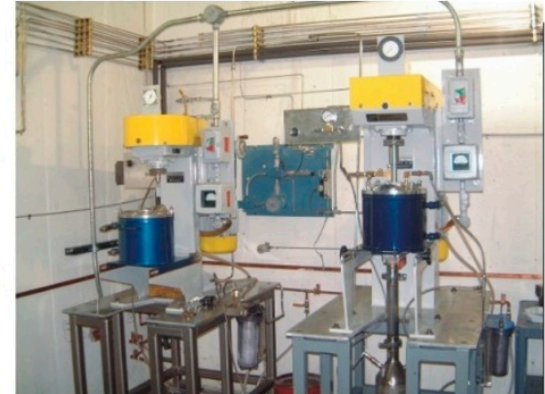

(b)

Figure 9. Images of (a) a shaker mill (Spex, Metuchen, NJ, USA) and (b) an attritor used in MA processes (Union Process, Akron, OH, USA). 
Table 2. Comparison between alloy preparation methods. VIM, CC, MS, GA, MA, AM, and PS are short for vacuum induction melting, centrifugal casting, melt spinning, gas atomization, mechanical alloying, arc melting, and plasma spray, respectively.

\begin{tabular}{|c|c|c|c|c|c|c|c|}
\hline Properties & VIM & $\mathrm{CC}$ & MS & GA & MA & AM & PS \\
\hline Purpose & Production & Research/Production & Research/Production & Research/Production & Research & Research & Research \\
\hline Batch Size & $1-1000 \mathrm{~kg}$ & $1-1000 \mathrm{~kg}$ & $1-200 \mathrm{~kg}$ & $1-1000 \mathrm{~kg}$ & $1-1000 \mathrm{~g}$ & $5-200 \mathrm{~g}$ & $5-100 \mathrm{~g}$ \\
\hline Equipment Cost & Medium & High & High & High & Low & Low & High \\
\hline Production Cost & $\$ 3 \mathrm{~kg}^{-1}$ & $\$ 4 \mathrm{~kg}^{-1}$ & $\$ 4 \mathrm{~kg}^{-1}$ & $\$ 5 \mathrm{~kg}^{-1}$ & $\$ 1000 \mathrm{~kg}^{-1}$ & $\$ 1000-\$ 5000 \mathrm{~kg}^{-1}$ & $\$ 2000 \mathrm{~kg}^{-1}$ \\
\hline Cooling Rate & $100^{\circ} \mathrm{C} \mathrm{s}^{-1}$ & $1 \times 10^{3}{ }^{\circ} \mathrm{C} \mathrm{s}^{-1}$ & $1 \times 10^{6}{ }^{\circ} \mathrm{C} \mathrm{s}^{-1}$ & $1 \times 10^{4}{ }^{\circ} \mathrm{C} \mathrm{s}^{-1}$ & $>1 \times 10^{6}{ }^{\circ} \mathrm{C} \mathrm{s}^{-1}$ & $500^{\circ} \mathrm{C} \mathrm{s}^{-1}$ & $1 \times 10^{4}{ }^{\circ} \mathrm{C} \mathrm{s}^{-1}$ \\
\hline Micro-structure & Large crystallites & Medium crystallites & Nano-crystallites & Micro-crystallites & Amorphous & Large crystallites & Micro-crystallites \\
\hline Alloy Discharge Capacity & Normal & Normal & Low & Low & High & Normal & Low \\
\hline Alloy High-Rate Discharge-ability & Normal & Normal & High & Low & High & Normal & High \\
\hline Alloy Cycle Stability (Anti-pulverization) & Normal & Better & Excellent & Excellent & Excellent & Normal & Excellent \\
\hline
\end{tabular}




\subsection{Particle Size Reduction}

Particle size influences capacity and high-rate dischargeability (HRD) behavior, but not activation properties [46]. As such, a proper particle size is required for battery operation. Unlike the conventional jar crusher used for $\mathrm{AB}_{5} \mathrm{MH}$ alloys, the high hardness of $\mathrm{C} 14 \mathrm{MH}$ alloys requires a hydrogenation process to create fissures and cracks for further grinding [47]. A stationary hydrogen reactor for laboratory use (2-kg load), a prototype rotational hydrogen reactor $(50 \mathrm{~kg})$, and a mass production stationary hydrogen reactor ( 5 tons) are shown in Figure 10. Operation details for the stationary and rotational hydrogen reactors can be found in the associated U.S. Patents $[48,49]$. Further reduction to a desirable size can be achieved by crushing [50], dry ball milling [51], wet ball milling [52], centrifugal grinding, or jet milling [53]. Three different powder fabrication methods-hydrogenation, dry ball milling, and wet ball milling —on a F-treated $\mathrm{AB}_{2} \mathrm{MH}$ alloy, were compared and the third showed the best electrochemical performance [54].

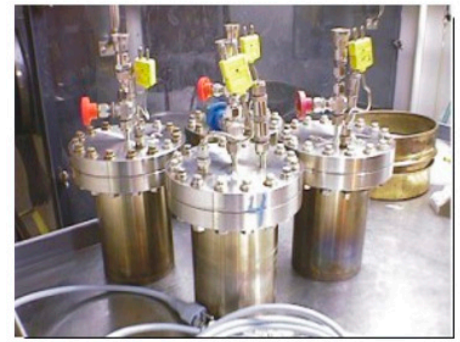

(a)

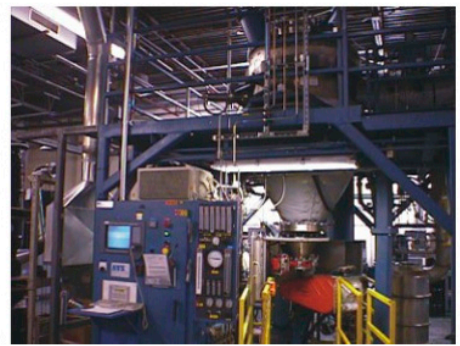

(b)

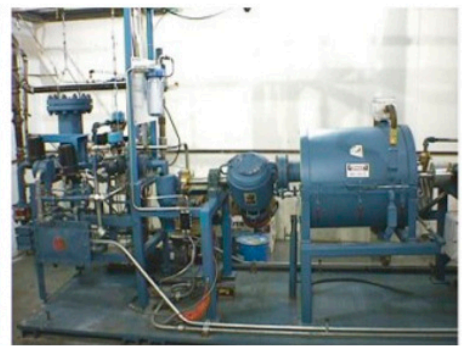

(c)

Figure 10. Images of (a) a 2-kg stationary, (b) a 3-ton stationary, and (c) a 20-kg rotational hydrogen reactors. While the first one was taken in BASF-Ovonic, the rest of two were taken in Eutectix.

\subsection{Annealing}

The main purpose of annealing is to improve uniformity in both composition and micro-structure. Annealing is a necessary step to prepare commercial grade $A_{5} \mathrm{MH}$ alloys with a long cycle life [55] (Figure 11a,b). In the case of $\mathrm{AB}_{2} \mathrm{MH}$ alloys, non-Laves secondary phases improve the electrochemical properties of an alloy [56] through synergetic effects [57] and are diminished by annealing treatments [58-61]. Therefore, annealing is not required for $\mathrm{AB}_{2} \mathrm{MH}$ alloys, except for those prepared by GA and with a surface oxide layer, which can be reduced to the metallic state by annealing in hydrogen [62] (Figure 11c). Annealing in Ar was also improved the capacity of GA- [63] and MS- [64] produced $\mathrm{AB}_{2} \mathrm{MH}$ alloys because of the ability to increase the surface crystallinity. The positive contribution of thermal annealing to electrochemical capacity was previously reported by Klein et al. [65].

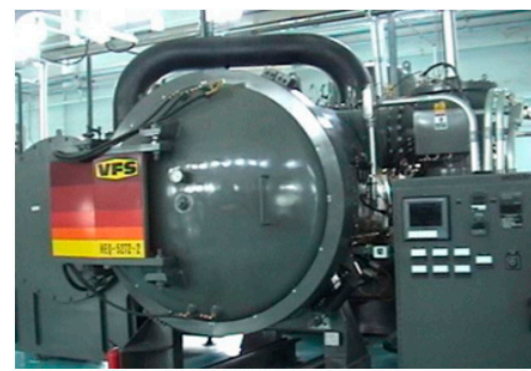

(a)

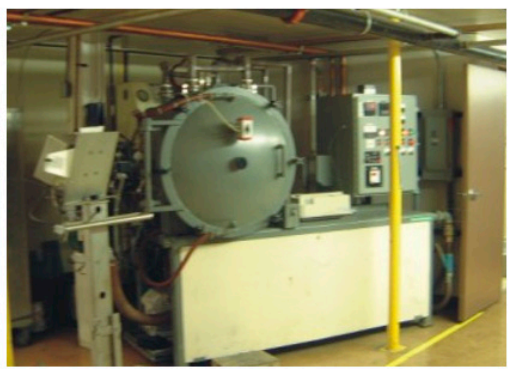

(b)

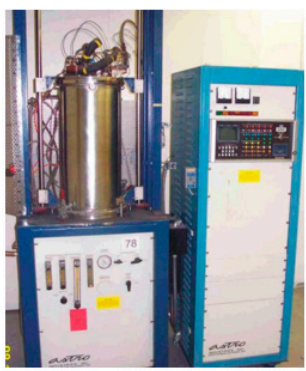

(c)

Figure 11. Images of (a) a 4-ton vacuum annealer, (b) a 200-kg vacuum annealer, and (c) a 10-kg flowing-hydrogen annealer. These pictures were taken in Rare-earth Ovonic Metal Hydride Company, Ovonic-BASF, and Eutectix. 


\subsection{Surface Treatment}

Various surface treatments are available for $\mathrm{AB}_{2} \mathrm{MH}$ alloys. A fluorination process can improve the surface anti-corrosion capability [66-71] and HRD [72], while a hot alkaline bath helps remove the native oxide that forms during the processes and creates a less dense oxide with catalytic $\mathrm{Ni}$, which further increases the surface's catalytic ability [51,66,73,74] and HRD [72]. Other methods include hot-charging performed at $80{ }^{\circ} \mathrm{C}$ [75], surface treatment in $\mathrm{NH}_{4} \mathrm{~F}$ and $\mathrm{NiCl}_{2}$ solution [76], $\mathrm{NiO}$ coating by the sol-gel method [77], electroless $\mathrm{Cu}$-coating [78], ball-milling with [79,80] or without Ni powder [81,82], ball-milling with La-containing $\mathrm{AB}_{5}$ or $\mathrm{A}_{2} \mathrm{~B}_{7} \mathrm{MH}$ alloys [83], and surface reduction by $\mathrm{KBH}_{4}$ and $\mathrm{NaBH}_{4}[84]$.

\section{Performance Criteria}

The general requirements for an $\mathrm{MH}$ alloy that is suitable for use as the negative electrode in $\mathrm{Ni} / \mathrm{MH}$ batteries include high electronic conductivity, a durable anti-corrosion surface, high $\mathrm{H}$-storage capability, fast bulk hydrogen diffusibility, adequate metal-hydrogen (M-H) bond strength, acceptable cost, small lattice expansion during hydrogenation, and environmental friendliness $[85,86]$. As the applications of $\mathrm{Ni} / \mathrm{MH}$ batteries become more versatile, the demands of $\mathrm{MH}$ alloys also vary. We classify the prerequisites of specific alloy properties in accordance with application in Table 3. For the $A_{2} M H$ alloys, the surface catalytic ability is not as good as those in $A B_{5}$ and $A_{2} B_{7} M H$ alloys, because of its lower $\mathrm{B} / \mathrm{A}$ ratio, which contributes to a lower level of metallic $\mathrm{Ni}$ on the surface [87]. But the corrosion product of $\mathrm{AB}_{2}$ alloy is dissoluble in electrolyte, which is different from the highly packed oxide of rare earth elements (RE) in $\mathrm{AB}_{5}$ alloys, and makes it a better candidate for high-temperature applications. The small hysteresis found in the pressure-concentration-temperature (PCT) analysis between absorption and desorption isotherm in $\mathrm{AB}_{2}$ reduces the pulverization rate and helps improve cycle stability $[88,89]$.

Table 3. Performance requirements of $\mathrm{MH}$ alloy in various type of applications. The symbols are ++ (highly desirable), + (important), 0 (not critical), and $\times$ (unrelated). EV and HEV represent electric vehicle and hybrid electric vehicle, respectively.

\begin{tabular}{|c|c|c|c|c|c|}
\hline Alloy Requirements & $\begin{array}{l}\text { High-Energy } \\
\text { (EV) }\end{array}$ & $\begin{array}{l}\text { High-Power } \\
\text { (HEV) }\end{array}$ & $\begin{array}{c}\text { Stationary } \\
\text { General Purpose }\end{array}$ & $\begin{array}{l}\text { Stationary at High } \\
\text { Temperature }\end{array}$ & $\begin{array}{c}\text { Stationary at Low } \\
\text { Temperature }\end{array}$ \\
\hline H-storage Capacity & ++ & 0 & + & + & + \\
\hline H-diffusibility & + & ++ & + & + & ++ \\
\hline Surface Catalysis & + & ++ & + & ++ & ++ \\
\hline Anti-corrosion & + & 0 & + & ++ & + \\
\hline Equilibrium Pressure & 0 & ++ & 0 & $\times$ & ++ \\
\hline Pulverization & ++ & + & 0 & + & + \\
\hline Cost & ++ & + & ++ & + & + \\
\hline
\end{tabular}

\section{Failure Mechanism}

While the failure mechanism of the $\mathrm{AB}_{5} \mathrm{MH}$ alloy has been studied extensively and reviewed in detail [90], similar studies on $\mathrm{AB}_{2} \mathrm{MH}$ alloys are rare [91,92]. Unlike the surface of $\mathrm{AB}_{5} \mathrm{MH}$ alloys, which are covered by an inert layer of $\mathrm{La}(\mathrm{OH})_{3}$ after numerous cycles, the $\mathrm{AB}_{2} \mathrm{MH}$ alloy forms soluble complex ions, including $\mathrm{HZrO}_{3}{ }^{-}, \mathrm{HMnO}_{2}{ }^{-}$, and $\mathrm{AlO}_{2}{ }^{-}$, which migrate through the separator into the positive electrode, causing micro-shorts and particle pulverization at the electrodes, which leads to positive electrode failure. The surface passivation of $\mathrm{AB}_{5} \mathrm{MH}$ alloys causes stable capacity degradation, while the failure at the positive electrode with $\mathrm{AB}_{2} \mathrm{MH}$ alloys creates a pressure increase, cell venting, and a sudden capacity drop near the end of the cycle life (Figure 12). Three $\mathrm{AB}_{2} \mathrm{MH}$ alloy degradation modes (oxidation, pulverization, and amorphization) are discussed in this section. 


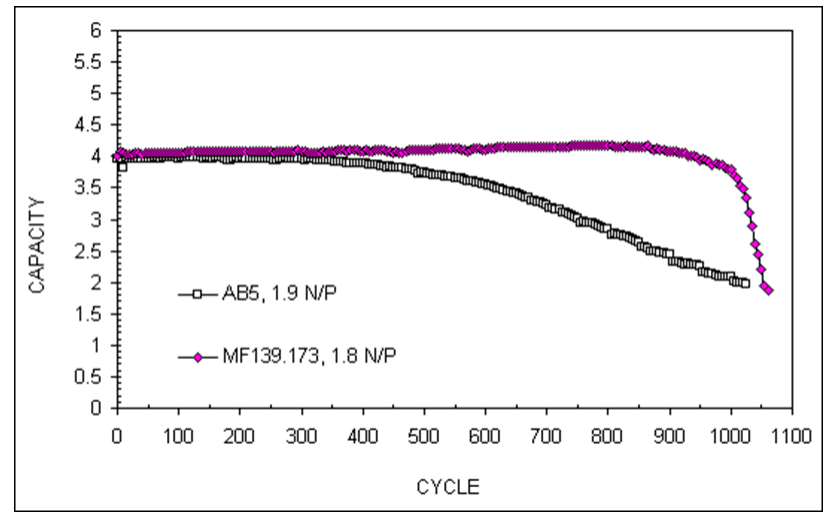

Figure 12. Comparison of cycle life in C-sized cell from $\mathrm{AB}_{5}$ and $\mathrm{AB}_{2}\left(\mathrm{MF} 139.173, \mathrm{Ti}_{12} \mathrm{Zr}_{21.5} \mathrm{~V}_{10} \mathrm{Cr}_{8.5}\right.$ $\mathrm{Mn}_{13.6} \mathrm{Co}_{1.5} \mathrm{Ni}_{32.2} \mathrm{Sn}_{0.3} \mathrm{Al}_{0.4}$ ) alloys as negative electrode active materials. $\mathrm{N} / \mathrm{P}$ denotes the ratio of capacities of negative and positive electrodes and capacity in the unit of Ah was obtained with a C/2 charge rate and a C/2 discharge rate to $0.9 \mathrm{~V}$ cell voltage.

\subsection{Oxidation}

The activated (alkaline bath treated or cycled) $\mathrm{AB}_{2}$ alloy surface consists of a top non-electrochemical reactive $\mathrm{ZrO}_{2}$ patch, a surface oxide $(\sim 200 \mathrm{~nm})$ with embedded metallic $\mathrm{Ni} / \mathrm{Co}$-clusters [10,93], and an amorphous buffer layer $(\sim 100 \mathrm{~nm})$ underneath [94]. In one example, the $\mathrm{Zr} / \mathrm{Ti}$ ratios are 8.2, 1.2, 0.8 , and 1.9 for the top oxide, supporting oxide, buffer oxide, and bulk, respectively, which indicates a higher leaching rate for $\mathrm{Zr}$ compared to that of $\mathrm{Ti}$ [94]. The metallic inclusions on the surface of the $\mathrm{AB}_{2}$ alloy were thought to be vital for the surface electrochemical reaction until it was determined that electrolyte-conducting channels coated with catalysts on the surface of the inner side of the alloy bulk can significantly improve low-temperature performance [95]. The leaching rates of constituent elements from a typical C14 MH alloy are calculated in Table 4 and follow the trend of $\mathrm{Al}>\mathrm{V}>\mathrm{Zr}>\mathrm{Ti}>\mathrm{Mn}$. Oxidation and pulverization are the major capacity degradation mechanisms for $\mathrm{AB}_{2} \mathrm{MH}$ alloys $[96,97]$.

Table 4. Calculation of leaching rate in $100{ }^{\circ} \mathrm{C} / 30 \% \mathrm{KOH}$ of a $\mathrm{C} 14 \mathrm{MH}$ alloy with a composition of $\mathrm{Ti}_{12} \mathrm{Zr}_{21.5} \mathrm{~V}_{9.5} \mathrm{Cr}_{4.5} \mathrm{Mn}_{13.6} \mathrm{Co}_{2} \mathrm{Ni}_{36.2} \mathrm{Sn}_{0.3} \mathrm{Al}_{0.4}$. Data are from [87].

\begin{tabular}{cccccc}
\hline Element & Ti & Zr & V & Al & Mn \\
\hline Amount in alloy (at \%) & 12.0 & 21.5 & 9.5 & 0.4 & 13.6 \\
Concentration in solution after 1 h etching (ppm) & 0.6 & 15.6 & 11.4 & 7.8 & 0.4 \\
Concentration in solution after 4 h etching (ppm) & 1.0 & 48.9 & 33.8 & 28.1 & 0.5 \\
Leaching rate after 1 h etching (ppm/at \%) & 0.05 & 0.73 & 1.2 & 19.5 & 0.03 \\
Leaching rate after 4 h etching (ppm/at \%) & 0.08 & 2.27 & 3.6 & 70.2 & 0.04 \\
\hline
\end{tabular}

\subsection{Pulverization}

Particle pulverization is a key failure mode for $\mathrm{AB}_{2} \mathrm{MH}$ alloys, because it increases the surface area of the electrode, which leads to more severe oxidation [98]. High internal stress exists in $\mathrm{AB}_{2} \mathrm{MH}$ alloy after hydrogenation, and cannot be removed by annealing because of the beneficial multi-phase structure. Thus, the initial pulverization due to the internal stress in $\mathrm{AB}_{2} \mathrm{MH}$ alloys is more severe than that in $\mathrm{AB}_{5} \mathrm{MH}$ alloys. But, because of the synergetic effect between the main storage phase and the catalytic secondary phase, the PCT hysteresis (the main reason for pulverization during hydride/dihydride cycling) in $\mathrm{AB}_{2}$ is much smaller than that in $\mathrm{AB}_{5}$ and, thus, a small degree of pulverization during cycling is expected from $\mathrm{AB}_{2}$. Two $\mathrm{SEM}$ micrographs showing the pulverizations after activation (10 cycles) and near the end of cycle life (450 cycles) are presented in Figure 13. 
Interestingly, a V-free $\mathrm{AB}_{2} \mathrm{MH}$ alloy also shows a higher pulverization rate than a V-containing alloy [92].

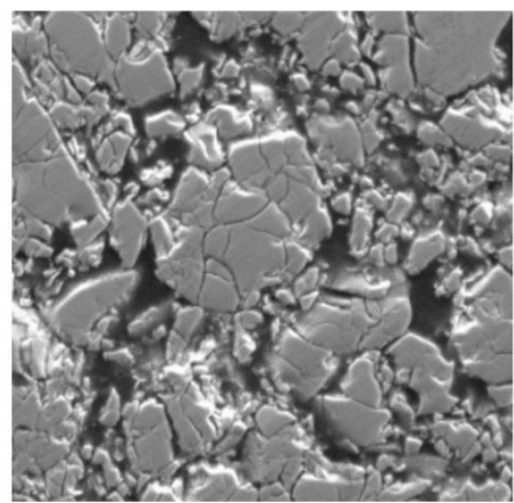

(a)

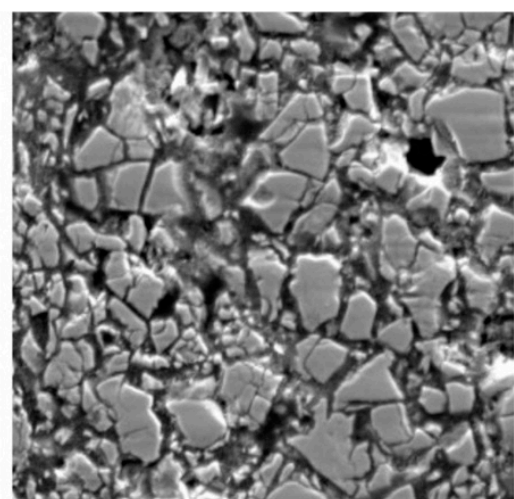

(b)

$$
\overline{20 \mu \mathrm{m}}
$$

Figure 13. SEM cross-section micrographs of a C14 MH alloy at (a) 10th cycle, just after initial activation and (b) 450th cycle, at the end of cycle life.

\subsection{Amorphization}

Hydrogen-induced-amorphization (HIA) frequently occurs on $\mathrm{AB}_{2}$ alloys $[99,100]$, especially those with an atomic radius ratio between $A$ - and $B$-site atoms $\left(R_{A} / R_{B}\right)>1.37$ [101]. The amorphous alloy may have a lower electrochemical capacity [101,102] but better HRD $[103,104]$ compared to its crystalline counterpart. An amorphous C14 MH alloy went through MA and its capacity decreased from 325 to $25 \mathrm{mAh} \cdot \mathrm{g}^{-1}$ [105]. A similar degradation of capacity caused by amorphization from MS has been previously reported [64].

\section{Non-Laves Secondary Phases}

During cooling from the liquid, the $\mathrm{C} 14$ phase solidifies first, followed by the $\mathrm{C} 15$ phase, and then finally a TiNi phase. The TiNi phase further transforms into $\mathrm{Zr}_{7} \mathrm{Ni}_{10}, \mathrm{Zr}_{9} \mathrm{Ni}_{11}$, and $\mathrm{ZrNi}$ phases via solid-state reactions [106-109] (Figure 14). When other modifiers are present, additional secondary phases are also formed. These secondary phases may not store large amounts of hydrogen, but they may improve electrochemical performance through the synergetic effect [57].

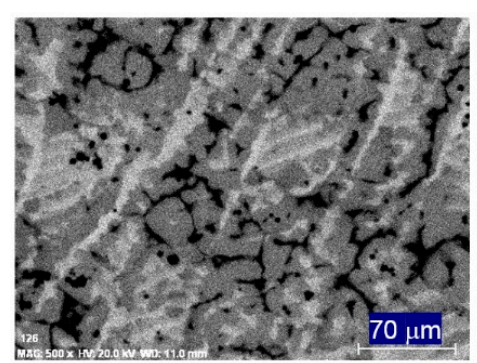

(a)

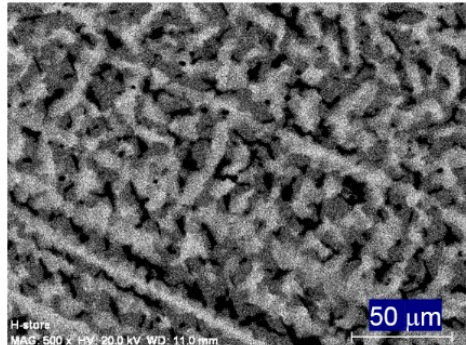

(b)

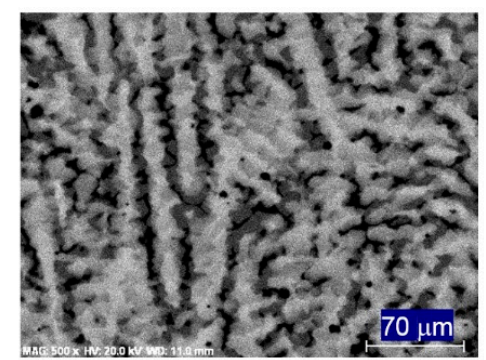

(c)

Figure 14. X-ray energy dispersive spectroscopy $\mathrm{Cr}$-mapping from $\mathrm{MH}$ alloys with (a) 3.5 at \% $\mathrm{Cr}$ and 28 wt \% C14, (b) 5.5 at \% Cr and 53 wt \% C14, and (c) 8.5 at \% Cr and 87 wt \% C14. The three phases are $\mathrm{C} 14, \mathrm{C} 15$, and $\mathrm{Zr}_{x} \mathrm{Ni}_{y}$ in order of decreasing brightness.

\subsection{TiNi}

A TiNi phase is a commonly observed secondary phase in C14 MH alloys. TiNi has a large soluble $\mathrm{Zr}$ content [110]. Occasionally, the $\mathrm{Zr}$-content in the TiNi phase can be larger than the 
Ti-content [111]. A TiNi phase was found to increase the discharge capacity, and to improve the charge retention and cycle life while lowering HRD capability [56]. In addition, it is known to improve low-temperature kinetics [112,113]. The electrochemical performances of TiNi-based MH alloys were previously reported [114-117].

\section{2. $Z r_{x} N i_{y}$}

Three Zr-dominated secondary phases are commonly seen in C14 MH alloys, specifically $\mathrm{ZrNi}$ [30], $\mathrm{Zr}_{9} \mathrm{Ni}_{11}$ [65,118], and $\mathrm{Zr}_{7} \mathrm{Ni}_{10}$ [118]. $\mathrm{ZrNi}$ and $\mathrm{Zr}_{7} \mathrm{Ni}_{10}$ phases are found to increase HRD, but sacrifice capacity and cycle stability, while $\mathrm{Zr}_{9} \mathrm{Ni}_{11}$ does the opposite $[56,119]$. $\mathrm{Zr}_{7} \mathrm{Ni}_{10}$ gradually shifted to $\mathrm{Zr}_{9} \mathrm{Ni}_{11}$ as secondary phases in $\mathrm{C} 14 \mathrm{MH}$ alloys with increasing V-content [120]. The electrochemical properties of $\mathrm{ZrNi}$ [30,121-123], $\mathrm{Zr}_{9} \mathrm{Ni}_{11}$ [121,124,125], $\mathrm{Zr}_{7} \mathrm{Ni}_{10}$ [30,121,124-127], and other $\mathrm{Zr}_{8} \mathrm{Ni}_{21}$ [30,121,124,125,128], $\mathrm{Zr}_{2} \mathrm{Ni}_{7}$ [30,121,129], and $\mathrm{ZrNi}_{5}$ [130] based $\mathrm{MH}$ alloys are also available.

\subsection{V-Based bcc Solid Solution}

In the MH alloys with a high V-content, a V-based body-centered-cubic (bcc) is commonly observed [131-133]. This phase is unlikely to corrode and remains at the surface after activation [72]. As the $\mathrm{V}$-content and the $\mathrm{B} / \mathrm{A}$ ratio increases, the microstructure of the alloy will change from a predominated Laves phase into a Laves-phase-related bcc two-phase solid solution [134]. The electrochemical storage of the two-phase alloy is higher, but the HRD suffers in the Laves-phase alloy [135].

\section{4. $\mathrm{ZrO}_{2}$}

$\mathrm{ZrO}_{2}$ is formed during the melting stage and acts as an oxygen scavenger [136], which is ordinarily seen in C14 MH alloys with higher $\mathrm{Zr}$ /Ti ratios [111]. It forms a protective barrier against oxidation [72], but does not form hydride under normal operating conditions in batteries [137].

\subsection{Other Secondary Phases}

Other secondary phases can be detected using non-transition metal modifiers, such as RE. The solubility of RE in the C14 phase is extremely low and the addition of $\mathrm{Y}, \mathrm{La}, \mathrm{Ce}, \mathrm{Nd}$ results in the formation of YNi [138], LaNi [139], CeNi [140], and NdNi [141] phases, respectively. These RE-Ni phases are detrimental to the electrochemical performance of MH alloys [112]. Like RE-Ni, the ScNi secondary phase increased discharge capacity, but weakened cycle stability [142]. A combination of hypo-stoichiometry and the addition of RE can boost low-temperature alloy performance [113]. High Mg-content secondary phases have been detected and facilitate the activation process $[143,144]$. A $\mathrm{ZrC}$ phase was formed with a $\mathrm{C}$-addition and improves charge retention but deteriorates cycle life, $\mathrm{HRD}$, and low-temperature performance. $\mathrm{Zr}_{2} \mathrm{Ni}_{2} \mathrm{Sn}[56,136]$ and $\mathrm{Zr}(\mathrm{Ni}, \mathrm{Mn}) \mathrm{Sn}_{0.35}$ [145] phases can be found in alloys with a relatively high Sn-content and are detrimental to the alloys' electrochemical performance. The structure and properties of $\mathrm{Zr}_{2} \mathrm{Ni}_{2} \mathrm{Sn}$ have been reported [146].

\section{Selections of Element}

$A B_{2}$ alloys have a greater compatibility of constituent elements, compared to that of $A B_{5} M H$ alloys, because of their superb solubility of components and great number of available phases. The compatibility of substituting elements makes $\mathrm{AB}_{2}$ a better candidate to meet various application demands. Laves phase alloys are composed of A-site and B-site atoms (Figure 1). The A-site atom is usually larger than the B-site atom, but tends to shrink as the electronegativity of the B-site atom increases, resulting in electron transfer. The ideal $R_{\mathrm{A}} / R_{\mathrm{B}}$ is 1.225 [147]. 


\subsection{A-Site Element}

For electrochemical applications, $\mathrm{Ni}$, with an atomic radius of $1.377 \AA$ in the Laves phase, is the major B-site element [148], which limits the choice of A-site element to those with an atomic radius of approximately $1.68 \AA$. Some physical properties of the A-site atoms are summarized in Table 5 . Ti and $\mathrm{Zr}$ are the most frequently used A-site elements in Laves phase $\mathrm{MH}$ alloys because of their availability. $\mathrm{Zr}$ has the strongest $\mathrm{M}-\mathrm{H}$ bond (lowest heat of hydride formation [149]) and the adjustment of $\mathrm{Zr} / \mathrm{Ti}$ content is the most effective method to change M-H bond strength.

Table 5. Properties of A-site elements in $\mathrm{AB}_{2}$ alloys. IMC denotes intermetallic compound.

\begin{tabular}{|c|c|c|c|c|c|}
\hline Properties & $\mathrm{Ti}$ & $\mathrm{Zr}$ & Hf & $\mathrm{Nb}$ & $\mathbf{P d}$ \\
\hline Atomic Number & 22 & 40 & 72 & 41 & 46 \\
\hline Atomic Radius in $\mathrm{AB}_{2}$ & 1.614 & 1.771 & 1.743 & 1.625 & 1.521 \\
\hline Electronegativity & 1.54 & 1.33 & 1.30 & 1.60 & 2.20 \\
\hline Earth Crust Abundance (\%) & 0.66 & 0.013 & $3.3 \times 10^{-4}$ & $1.7 \times 10^{-3}$ & $6 \times 10^{-7}$ \\
\hline Melting Temperature $\left({ }^{\circ} \mathrm{C}\right)$ & 1668 & 1855 & 2150 & 2468 & 1555 \\
\hline$\Delta H_{\mathrm{h}}\left(\mathrm{kJ} \cdot \mathrm{mol} \mathrm{H}_{2}^{-1}\right)$ & -136 & -164 & -161 & -83 & -41 \\
\hline Number of IMCs with $\mathrm{Ni}$ & 3 & 8 & 8 & 3 & 0 \\
\hline
\end{tabular}

\subsubsection{Titanium}

Ti results in weaker M-H bond strength, higher PCT equilibrium pressure [65], and improved HRD performance [41,150,151]. Ti forms an inert layer of $\mathrm{TiO}_{2}$ and impedes activation [31,152], which improves cycle stability [153] and causes capacity degradation [154]. However, another group reported that $\mathrm{Ti}$ is beneficial for improving activation [155]. Ti-content impacts the discharge capacity in two competing ways: weaker M-H bonds lead to a lower capacity, but higher plateau pressure also improves the reversibility and increases the discharge capacity. Previous research has documented that increasing Ti-content has led to increasing [156-159], decreasing [155,158,160], and unchanged [150] electrochemical discharge capacities. A high Ti-content also contributes to a higher abundance of bcc phase [161] and a higher C14 abundance [162] because of its higher chemical potential [163].

\subsubsection{Zirconium}

To maintain stoichiometry in comparison to $\mathrm{AB}_{2}$, the sum of Ti- and $\mathrm{Zr}$-contents is approximately 33 at \%. Therefore, $\mathrm{Zr}$ has the opposite effects of Ti. A higher Zr-content will stabilize the hydride [163] and lower HRD [150]. The bulk oxide of $\mathrm{Zr}$ is usually formed during solidification and has a higher solubility in $\mathrm{KOH}$ solution than $\mathrm{TiO}_{2}$ [87]. A dense layer of $\mathrm{ZrO}_{2}$ formed on the surface of the $\mathrm{Zr}$ particles during powder processing (grinding, sifting, and packaging), and impedes the activation process $[152,164,165]$.

\subsubsection{Hafnium}

Not many studies have examined the electrochemical properties of Hf- substituted $A_{2} \mathrm{MH}$ alloys $[42,160]$. An XRD study confirms that $\mathrm{Hf}$ and Ti share the A-site and V and $\mathrm{Ni}$ are found in the B-site [166]. Hf-substitution yields a slightly smaller unit cell [167], which is unexpected because of its relatively large atomic radius (Table 5). The reduced lattice constant $c / a$ ratio with the addition of Hf [167] predicts a lower pulverization rate. Partially substituting Hf for Zr results in a lower electrochemical capacity, but a higher HRD [160].

\subsubsection{Niobium}

$\mathrm{Nb}$ occupying the A-site was confirmed by a Rietveld analysis with XRD data from a substituted $\mathrm{ZrCr}_{2}$ alloy [168]. Partial replacement of $\mathrm{Zr}$ by Nb leads to a smaller $\mathrm{C} 14$ unit cell volume and, consequently, a higher PCT plateau pressure [169]. It increases the C14 phase abundance and reduces 
lattice constants [167]. Like $\mathrm{Hf}, \mathrm{Nb}$ also contributes to a reduced lattice constant $c / a$ ratio [167] leading to a smaller pulverization rate. The $\mathrm{NiNb}$ secondary phase is a poor catalyst/H-storage material and, remarkably, reduces the surface exchange current [169]. Like Hf, $\mathrm{Nb}$-substitution deteriorates capacity [42], but enhances HRD [160].

\subsubsection{Palladium}

$\mathrm{Pd}$ is smaller than both $\mathrm{Ti}$ and $\mathrm{Zr}$, and when it enters the A-site, it reduces the unit cell of the Laves phases, which results in a decrease in discharge capacity. However, it also enhances the surface catalytic ability and improves both HRD and low-temperature performance for the alloy [170]. Improvement in HRD of C14 alloys was also reported by Yang, Ovshinsky, and their coworkers [171,172].

\subsubsection{Scandium}

Use of $\mathrm{Sc}$, another expensive additive, in $\mathrm{AB}_{2} \mathrm{MH}$ alloy is scarce. The gaseous phase H-storages of $\mathrm{C} 15 / \mathrm{C} 36 \mathrm{ScM}_{2}(M=\mathrm{Fe}, \mathrm{Co}$, and $\mathrm{Ni})$ were reported [173] with an electrochemical study of a C15 $\mathrm{ScNiCo}_{0.2} \mathrm{Mn}_{0.5} \mathrm{Cr}_{0.2}$ alloy [174]. The partial replacement by $\mathrm{Zr}$ and $\mathrm{Y}$ in Sc-based $\mathrm{C} 15$ showed cycle stability improvement with the corresponding sacrifice in discharge capacity [142]. The addition of Sc increased the abundance of the ZrNi secondary phase, improved the activation and capacity, but resulted in a trade-off in HRD [175].

\subsection{B-Site Element}

$\mathrm{Ni}$ is the most widely used B-site element in alkaline battery applications. However, $\mathrm{Ti}, \mathrm{Zr}$, and their mixture do not form Laves phase intermetallic compound (IMC) with Ni [176]. Therefore, B-site substitutions, mainly from the first row of transition metals-because of their availability and light weight-are essential for the stability of Laves phase IMC. Both the electron affinity and the atomic radius decrease as the atomic number of the modifier atom increases, which reduces the average metal-hydrogen bond strength, increases plateau pressure, and decreases $\mathrm{H}$-storage capacity. With different solubility and chemical properties related to corrosion, these modifier elements are crucial for engineering various electrochemical properties and will be reviewed in the following sections. Various properties of the first-row transition metals are summarized in Table 6. The atomic radius of the element decreases as the atomic number increases until $\mathrm{Ni}$ and then increases from $\mathrm{Cu}$ and $\mathrm{Zn}$. The number of IMC with Ti also increases roughly with increasing atomic number.

Table 6. Properties of first-row transition metal elements as B-site atoms in $\mathrm{AB}_{2}$ alloys.

\begin{tabular}{|c|c|c|c|c|c|c|c|c|}
\hline Properties & $\mathbf{V}$ & $\mathrm{Cr}$ & Mn & Fe & Co & $\mathrm{Ni}$ & $\mathrm{Cu}$ & $\mathrm{Zn}$ \\
\hline Atomic Number & 23 & 24 & 25 & 26 & 27 & 28 & 29 & 30 \\
\hline Atomic Radius in $\mathrm{AB}_{2}$ & 1.491 & 1.423 & 1.428 & 1.411 & 1.385 & 1.377 & 1.413 & 1.538 \\
\hline Electronegativity & 1.63 & 1.66 & 1.55 & 1.83 & 1.88 & 1.91 & 1.90 & 1.65 \\
\hline Earth Crust Abundance (\%) & 0.019 & 0.014 & 0.11 & 6.3 & 0.003 & 0.009 & 0.007 & 0.008 \\
\hline Melting Temperature $\left({ }^{\circ} \mathrm{C}\right)$ & 1890 & 1857 & 1245 & 1535 & 1495 & 1453 & 1083 & 420 \\
\hline$\Delta H_{\mathrm{h}}\left(\mathrm{kJ} \cdot \mathrm{mol} \mathrm{H}_{2}^{-1}\right)$ & -35 & -8 & -8 & 10 & 15 & -3 & 20 & 8 \\
\hline Number of IMCs with Ti & 0 & 1 & 1 & 2 & 4 & 3 & 5 & 7 \\
\hline
\end{tabular}

\subsubsection{Vanadium}

$\mathrm{V}$ is the only B-site element that brings high $\mathrm{H}$-storage capacity [17]. It results in a more stable hydride, more disorder, but also decreases peak power and charge retention [177]. The high leaching rate of $\mathrm{V}$ is the main cause of poor charge retention in conventional $\mathrm{V}$-containing $\mathrm{MH}$ alloys [87,178]. The high electronic conductivity of $\mathrm{V}$ also improves the activation property of alloys [179]. A balance of V-content is needed to optimize battery performance [180]. V-free MH C14 MH alloys were designed to address the charge retention issue, but did so at the expense of cycle stability $[144,178]$. The large atomic radius of $\mathrm{V}$ enlarges the alloy unit cell and reduces the volume expansion during hydrogenation, 
which in turn reduces PCT hysteresis and pulverization tendency [181], which results in a shorter cycle life [42]. Reports of V lowering capacity are also available [42].

\subsubsection{Chromium}

The addition of $\mathrm{Cr}$ in C14 MH alloys improves cycle stability [11,131,182-185] and charge retention $[11,184,186]$ but decreases the $\operatorname{HRD}[11,186,187]$, capacity [131], and activation tendency [11]. Cr can suppress segregation of $\mathrm{Ti}, \mathrm{Zr}$, and $\mathrm{V}$ on the surface of $\mathrm{MH}$ alloys [188], retarding the oxidation of $\mathrm{V}$ by forming a V-based bcc solid solution secondary phase [131,189], and slowing down pulverization [190]. Retarding HRD by adding $\mathrm{Cr}$ was further attributed to poor bulk hydrogen diffusibility and surface exchange current [133]. Compared to $\mathrm{Co}, \mathrm{Cr}$ promotes a dendritic grain structure that is beneficial for cycle stability [118]. Its capability of reducing PCT hysteresis also contributes to a longer cycle life [11].

\subsubsection{Manganese}

Partial replacement of Ni by Mn increases capacity [17,186], facilitating the formation process [186], but deteriorating the cycle life of the battery because of its poor oxidation resistance $[186,191]$ and results in micro short-circuits [192]. A high Mn-content in an alloy reduces the cycle life and charge retention because of poor oxidation resistance in the $\mathrm{KOH}$ electrolyte [11]. A low Mn-content provides improves activation, capacity, and HRD [193]. Therefore, a careful balance between the content of $\mathrm{Mn}$ - and other B-elements is necessary to optimize battery performance [11,42]. In a separate report, Mn was found to increase the discharge capacity and exchange current density while hindering HRD and cycle stability [194]. Mn facilitates homogenizing the chemical composition of different constituent phases in a multi-phase alloy system [11].

\subsubsection{Iron}

In V-containing C14 alloys, the addition of Fe facilitates activation, increases the discharge capacity and surface reaction area, decreases HRD [131] and hydrogen diffusibility, and impairs low-temperature performance [195]. However, reports also suggest that Fe contributes to a low capacity [42] and higher cycle life [196,197]. In a V-free C14 alloy, the addition of Fe improves low-temperature performance, but hinders cycle life and charge retention [144]. The solubility of Fe in $\mathrm{Zr}_{7} \mathrm{Ni}_{10}$ and $\mathrm{Zr}_{9} \mathrm{Ni}_{11}$ phases is lower than that in TiNi phases, which explains the promotion of TiNi phase by Fe-addition [195].

\subsubsection{Cobalt}

Co promotes an equiaxial grain structure that improves surface reaction kinetics, activation, and capacity, but deteriorates cycle stability [196]. An optimal Co-content in a C14 MH alloy of 1.5 at \% provides the best performance in terms of formation, cycle life, and charge retention, but exhibits worse specific power and low-temperature performance compared to other compositions [111]. Compared to other modifiers, such as $\mathrm{Fe}, \mathrm{Cu}, \mathrm{Mo}$, and $\mathrm{Al}, \mathrm{Co}$-substituted $\mathrm{C} 14 \mathrm{MH}$ alloys show a relatively higher discharge capacity $[120,198,199]$, good cycle performance [120,193,199], and poor HRD [152]. Reports on Co-substituted C14 MH alloys with increased plateau pressure [200], a reduced capacity [200], and a lower cycle life [42] are also available.

\subsubsection{Nickel}

$\mathrm{Ni}$ is the most efficient catalytic B-site element because of the formation of metallic clusters embedded in the surface oxide after activation $[87,201,202]$. The introduction of Ni greatly improves electrochemical behavior [203], HRD [11], low-temperature performance [11,202], surface exchange current [204], and cycle stability [186], but impedes charge retention [11]. 


\subsubsection{Copper}

In a typical $\mathrm{C} 14 \mathrm{MH}$ alloy, the addition of $\mathrm{Cu}$, with is high degree of pulverization, facilitates activation processes and improves discharge capacity and low-temperature performance, but decreases HRD because of lower hydrogen diffusibility [205]. Cu has also been reported to impair cycle stability [206] and lower capacity [42].

\subsubsection{Zinc}

Zn has an extremely low melting point compared to its neighbors' in the periodic table (Table 6) and is unable to remain in the $\mathrm{C} 14$ alloy at a melting point above $1350{ }^{\circ} \mathrm{C}$. Therefore, $\mathrm{ZnNi}$ [207] and $\mathrm{ZnCu}$ [208] IMCs were used as raw materials to reduce $\mathrm{Zn}$ loss from evaporation. 1 at \% $\mathrm{Zn}$ results in an increase in discharge capacities, a slight decrease in HRD, an easier activation process, and a satisfactory low-temperature performance [207].

\subsubsection{Second Row Transition Metals (Mo)}

Mo is the only element in the second row of transition metals that is used as a modifier in the C14 $\mathrm{MH}$ alloys, as it is accessible and not very toxic. According to our recent study, partial substitution of Co by Mo in a C14 MH alloy increases both the bulk diffusibility of hydrogen and surface catalytic ability, which leads to improved HRD and low-temperature performance [209]. Mo also improves charge retention and cycle stability, but yields a slightly lower capacity [209]. The cycle stability improvement of C14 MH alloy using Mo was also reported [42]. However, reports on the negative impact of Mo on the capacity, cycle life, and activation of C14 MH alloy are also available, presumably due to lack of Cr or Co in the composition [197,199]. Partially replacing Cr with Mo increases the gaseous phase H-storage capacity [210,211], ease of activation, and HRD [212].

\subsubsection{Third Row Transition Metals (W, Pt)}

$\mathrm{W}$ and Pt are the only two elements in the third row of the transition metals that are used because of concerns with availability and weight. $\mathrm{W}$ improves corrosion resistance and self-discharge of $\mathrm{C} 14$ $\mathrm{MH}$ alloys [213]. The addition of $\mathrm{Pt}$ in a $\mathrm{C} 14 \mathrm{ZrCrNi}$ alloy with an annealing treatment improved HRD and capacity because of the high catalytic activity of $\mathrm{Pt}$ for hydrogen electrosorption processes [214].

\subsubsection{Group 13 Elements (B, Al)}

B exhibits excellent solubility in V-free C14 MH alloys and contributes to a lower capacity, a high HRD, and improved superior low-temperature performance [144]. In V-containing alloys, B increased cycle stability [215] and bulk diffusion [216], however it also results in decreased capacity and HRD [216]. Reports on the positive contributions of B to HRD and low-temperature performance in V-containing C14 alloys are also available [217]. Ball milling C14 alloys with B show improved cycle stability at the cost of a lowered capacity [218].

$\mathrm{Al}$ is the most frequently used non-transition metal in Laves phase $\mathrm{MH}$ alloys. Al use has been shown to strongly correlate with a high capacity and a good HRD performance [219]. Al additives, together with $\mathrm{Co}$, positively contribute to activation, charge retention, $\mathrm{HRD}$, and low-temperature performances $[136,220]$. In the gaseous phase, $\mathrm{Al}$ was also shown to reduce PCT hysteresis, which in turn retards pulverization [200]. This also contributes to a lower flammability, which enhances safety in powder handling [221]. Even with the highest leaching out rate observed in Table 4, $\mathrm{Al}$ has been reported to improve the corrosion resistance of alloys, leading to better charge retention performance $[164,213,222]$.

\subsubsection{Group 14 Elements (C, $\mathrm{Si}, \mathrm{Ge}, \mathrm{Sn})$}

In V-free C14 alloys, the addition of $\mathrm{C}$ promotes the formation of a $\mathrm{ZrC}$ secondary phase and improves charge retention, but also deteriorates low-temperature performance, cycle life, 
and HRD [144]. In a Ti-only C14 alloy, adding C promoted the formation of a TiC secondary phase, which facilitated the activation and decreased the gaseous phase $\mathrm{H}$-storage capacity [223]. In one Zr-based C14 MH alloy, C improved cycle stability [17].

The addition of $\mathrm{Si}$ to $\mathrm{C} 14 \mathrm{MH}$ alloys improved the self-discharge [17], high-temperature discharge performances $[17,224,225]$, low-temperature performance [226], and cycle stability $[17,226]$ with trade-offs for lower capacity caused by an inert layer of $\mathrm{SiO}_{2}$ on the surface of the alloy [224,225]. Si-incorporated C15 MH alloys' improved low-temperature performance is attributed to a layer of $\mathrm{Ni}_{2} \mathrm{O}_{3}$ that formed on the metal surface and can be detected by transmission electron microscopy (TEM, CM200/FEG, Philips, Amsterdam, The Netherlands) [227]. Si also contributes to a lower flammability that enhances safety in powder handling [221]. Both $\mathrm{Si}$ and Ge additives to $\mathrm{ZrCr}_{2} \mathrm{MH}$ alloy reduce gaseous phase H-storage capacity [228].

$\mathrm{Zr}$ is widely used in nuclear power plants because of its stability from a low neutron scattering cross-section. The costly separation process from Hf (neutron absorber) makes pure $\mathrm{Zr}$ metal expensive [229]. Future cost reduction of $\mathrm{Zr}$ is expected as the demand of a Hf-containing $\mathrm{Zr}$ for battery applications (Hf impurities do not matter since $\mathrm{Hf}$ is also a hydride former) increases. Currently, a large amount of Zircaloy (a Sn-Zr alloy [230]) scrap is available from demolished nuclear power plants and the addition of $\mathrm{Sn}$ is essential for cost reduction in raw materials. According to our own study, a small amount of $\mathrm{Sn}(0.1$ at \%) can improve activation, HRD, charge retention, and low-temperature performances at the expense of capacity and cycle life loss [219,231]. Sn also promotes the formation of detrimental secondary phases. Thus, the content of Sn should be limited [145].

\subsubsection{Group 16 Elements $(\mathrm{O}, \mathrm{S}, \mathrm{Se})$}

The only report on the addition of $\mathrm{O}, \mathrm{S}$, and Se to $\mathrm{C} 14 \mathrm{MH}$ alloys compares gaseous phase characteristics and shows the same order of effectiveness $(\mathrm{S}>\mathrm{Se}>\mathrm{O})$ in raising plateau pressure and PCT hysteresis, increasing storage capacity, and reducing the PCT slope factor [232].

\subsection{Secondary Phase Promoter}

The addition of elements with large atomic radii, but extremely low solubility in $\mathrm{Ti}-\mathrm{Zr}$ based $\mathrm{AB}_{2}$ $\mathrm{MH}$ alloys, in the Laves phase will form secondary phases either in an element form or a Ni-containing alloy form. These secondary phases may play an important role in the electrochemical performance of the host alloy.

\subsubsection{Group 1 Elements $(\mathrm{Li}, \mathrm{K})$}

$\mathrm{Li}$ has an extremely low melting point and very high vapor pressure at liquid temperatures for $\mathrm{C} 14 \mathrm{MH}$ alloys, therefore adding $\mathrm{Li}$ at the last stage and in the mold results in failure. However, Li-incorporated $\mathrm{AB}_{5} \mathrm{MH}$ alloys with their lower melting temperature, were successfully prepared by AM [233], VIM [234], and a diffusion method [235]. Li did promote unidentified secondary phases, based on XRD analysis [235]. $\mathrm{KB}$ was added in a $\mathrm{Ti}_{2} \mathrm{Ni}$ based $\mathrm{MH}$ alloy as a source of $\mathrm{K}$ and showed improved cycle stability [215].

\subsubsection{Group 2 Elements $(\mathrm{Mg})$}

Solubility of $\mathrm{Mg}$ in the Laves phase is extremely low (0.1-0.3 at \% [143]). In V-containing C14 alloys, it forms a cubic secondary phase, which facilitated the formation process but did not improve other electrochemical properties [143]. In V-free C14 alloys, the addition of $\mathrm{Mg}$ formed a $\mathrm{Mg}_{2} \mathrm{Ni}$ secondary phase and improved low-temperature performance and charge retention, but hampered cycle life and $\mathrm{HRD}$ [144]. Ball milling with $\mathrm{Mg}_{2} \mathrm{Ni}$ can also introduce $\mathrm{Mg}$ into $\mathrm{AB}_{2} \mathrm{MH}$ alloys [236]. In recent years, $\mathrm{Mg}$ and La were introduced to $\mathrm{AB}_{2} \mathrm{MH}$ alloys by either remelting [237] or MA [238] with an $\mathrm{AB}_{2}$ / superlattice alloy mixture where superlattice alloys contain both $\mathrm{La}$ and $\mathrm{Mg}$. 


\subsubsection{Rare Earth (RE) Metals}

A great number of studies have focused on how to solve the slow activation of RE-incorporated C14MH alloys [67,165,184,239-243]. Low solubility of RE in Zr, Ti-based C14 IMC promotes a RE-Ni (AB) secondary phase and facilitates activation processes [244]. Properties of commonly used REs as modifiers in the $\mathrm{AB}_{2} \mathrm{MH}$ alloy are summarized in Table 7. $\mathrm{La}, \mathrm{Ce}$, and Sm are the least expensive. In general, the ionic radius, ease of oxidation, and $\mathrm{MH}$-bond strength become smaller when the atomic number increases. Previous studies in a comparison series of RE-doped C14 MH alloys [112,113,138-141] showed that the RE-Ni phase is beneficial for activation, but detrimental to HRD and low-temperature performance, and that a careful stoichiometric design is needed to balance the abundance of the RE-Ni and TiNi phases [113]. The incorporation of La provides the greatest low-temperature performance, but a contradictory microstructure (an increase in the detrimental LaNi phase and corresponding decrease in the beneficial TiNi phase). Further TEM studies indicated that the $\mathrm{Ni}-\mathrm{Cr}$ alloy channeled and catalyzed by a single-crystal sheet contributes to improvements in the surface catalytic ability of La-incorporated alloys [95]. Gd remains as a metallic inclusion when melted with C14 MH alloys and improves low-temperature performance, but deteriorates HRD, cycle stability, and charge retention [144]. Instead of using RE, which are nearly insoluble in Laves phase alloys, MA was used and achieved similar effects of capacity and activation [245]. In addition to adding RE in elemental form, RE-containing $\mathrm{AB}_{5}[246,247]$ and $\mathrm{A}_{2} \mathrm{~B}_{7}$ [248] can be used for similar results.

Table 7. Properties of some REs used as additives in $\mathrm{AB}_{2} \mathrm{MH}$ alloys.

\begin{tabular}{|c|c|c|c|c|c|c|c|c|}
\hline Properties & $\mathbf{Y}$ & La & $\mathrm{Ce}$ & $\operatorname{Pr}$ & Nd & Sm & Gd & $\mathbf{Y b}$ \\
\hline Atomic Number & 39 & 57 & 58 & 59 & 60 & 61 & 55 & 70 \\
\hline Price (US\$/kg) [249] & 35 & 7 & 7 & 85 & 60 & 7 & 55 & 95 \\
\hline Ionic Radius in Laves ( $\AA$ ) [148] & 1.990 & 3.335 & 2.017 & 2.013 & 2.013 & 1.990 & 1.992 & 1.990 \\
\hline Electronegativity & 1.22 & 1.10 & 1.12 & 1.13 & 1.14 & 1.17 & 1.20 & 1.24 \\
\hline Melting Temperature $\left({ }^{\circ} \mathrm{C}\right)$ & 1522 & 918 & 798 & 931 & 1021 & 1072 & 1313 & 819 \\
\hline Oxidation potential $(\mathrm{V})$ & -2.372 & -2.379 & -2.335 & -2.353 & -2.323 & -2.304 & -2.279 & -2.19 \\
\hline Heat of Hydride Formation $\left(\mathrm{kJ} \cdot \mathrm{mol} \mathrm{H}_{2}{ }^{-1}\right)$ [250] & -114 & -97 & -103 & -104 & -106 & -100 & -98 & -91 \\
\hline
\end{tabular}

\subsection{Summary of Modifier Studies}

Unlike $\mathrm{AB}_{5}, \mathrm{AB}_{2} \mathrm{MH}$ alloys are compatible with a remarkable number of elements. The degree of impact for commonly used elements on $\mathrm{MH}$ alloy properties are summarized in Table 8. Proper selection of elements can be based on the alloy requirements after checking each of the seven rows. Meanwhile, the pros and cons of each element can be easily evaluated in the corresponding column.

Table 8. Influence of commonly used modifiers to C14 alloy performance. The symbols are ++ (highly beneficial), + (beneficial), 0 (no significant effect), and - (detrimental). Degree of pulverization is the combination of actual measurement [88] and estimation from PCT hysteresis and C14 phase lattice constant ratio $a / c$. Equilibrium pressure changes are indicated with up or down arrows.

\begin{tabular}{|c|c|c|c|c|c|c|c|c|c|c|c|c|c|}
\hline Alloy Requirements & $\mathrm{Ti}$ & $\mathrm{Zr}$ & $\mathbf{V}$ & $\mathrm{Cr}$ & Mn & $\mathrm{Fe}$ & Co & $\mathbf{N i}$ & $\mathrm{Cu}$ & $\mathrm{Zn}$ & Al & Si & La \\
\hline H-storage Capacity & - & ++ & + & 0 & $0 /+$ & 0 & + & 0 & 0 & 0 & + & 0 & 0 \\
\hline H-diffusibility & + & - & - & 0 & 0 & - & 0 & 0 & - & + & + & + & + \\
\hline Surface Catalysis & - & + & + & - & - & - & 0 & ++ & - & + & + & + & ++ \\
\hline Anti-corrosion & + & - & - & ++ & - & 0 & 0 & ++ & 0 & 0 & 0 & 0 & 0 \\
\hline Equilibrium Pressure & $\uparrow \uparrow$ & $\downarrow \downarrow \downarrow$ & $\downarrow \downarrow$ & $\downarrow$ & $\downarrow$ & 0 & $\uparrow$ & $\uparrow$ & 0 & 0 & $\uparrow$ & 0 & 0 \\
\hline Anti-pulverization & + & - & 0 & - & 0 & 0 & 0 & 0 & - & - & + & - & 0 \\
\hline Cost & 0 & 0 & - & + & ++ & ++ & - & 0 & ++ & ++ & ++ & ++ & + \\
\hline
\end{tabular}

\section{Stoichiometry}

An IMC with a fixed stoichiometry comes with a large negative heat formation [45]. The different energy levels of anti-site and vacancy defects in a specific IMC may change its stoichiometry range [251-253]. If the energy for such defects is relatively low, a wide range of compositions (off-stoichiometry) are expected, among which $\mathrm{AB}_{2}$ Laves phase alloys make up the largest portion in 
IMC [21]. Compositions of a few IMCs based on Group 4 elements (Ti, Zr, and Hf) as A-site atoms are listed in Table 9 and plotted in Figure 15 as a function of $R_{A} / R_{B}$. IMCs with a C14 structure have a wider composition range (more likely to suffer from point defects) and the phase solubility of IMCs with a C15 structure becomes larger as the radii ratio increases. $A n A_{2}$ alloy with a $B / A$ ratio below 2.0 is a hypo-stoichiometric IMC. The reason that more hypo-stoichiometric IMCs tend to form as the radii ratio increases is that a relatively small B-atom more rapidly forms a double $\mathrm{B}$ in A-site (dumbbell model [254]) and further increases the B/A ratio. The characteristics of a few off-stoichiometric C14 MH alloys were previously compared $[45,255,256]$ and important results are summarized in the next three sections.

Table 9. Solubility (range of A-site atom concentration in at \%) of Laves phase IMCs (radius from [148] and solubility from [257]).

\begin{tabular}{|c|c|c|c|}
\hline IMC & Structure & $R_{\mathrm{A}} / R_{\mathrm{B}}$ & Solubility (at \%) \\
\hline $\mathrm{ZrV}_{2}$ & C15 & 1.19 & 33.3 \\
\hline $\mathrm{HfV}_{2}$ & C15 & 1.17 & $33.5-34.5$ \\
\hline $\mathrm{TiCr}_{2}$ & C15 & 1.13 & $35-37$ \\
\hline $\mathrm{ZrCr}_{2}$ & C15 & 1.24 & $31-36$ \\
\hline $\mathrm{HfCr}_{2}$ & C15 & 1.22 & $33-35$ \\
\hline $\mathrm{TiMn}_{2}$ & C14 & 1.13 & $30-40$ \\
\hline $\mathrm{ZrMn}_{2}$ & C14 & 1.24 & $20.8-40$ \\
\hline $\mathrm{HfMn}_{2}$ & C14 & 1.22 & $25.5-38$ \\
\hline $\mathrm{TiMn}_{2}$ & C14 & 1.14 & $27.5-35.5$ \\
\hline $\mathrm{ZrMn}_{2}$ & C15 & 1.26 & $27.1-34$ \\
\hline $\mathrm{HfMn}_{2}$ & C15 & 1.24 & $32-33.5$ \\
\hline $\mathrm{TiCO}_{2}$ & $\mathrm{C} 15$ & 1.17 & $33-33.5$ \\
\hline $\mathrm{ZrCo}_{2}$ & C15 & 1.28 & $27-35$ \\
\hline $\mathrm{HfCO}_{2}$ & C15 & 1.26 & $27-36$ \\
\hline
\end{tabular}

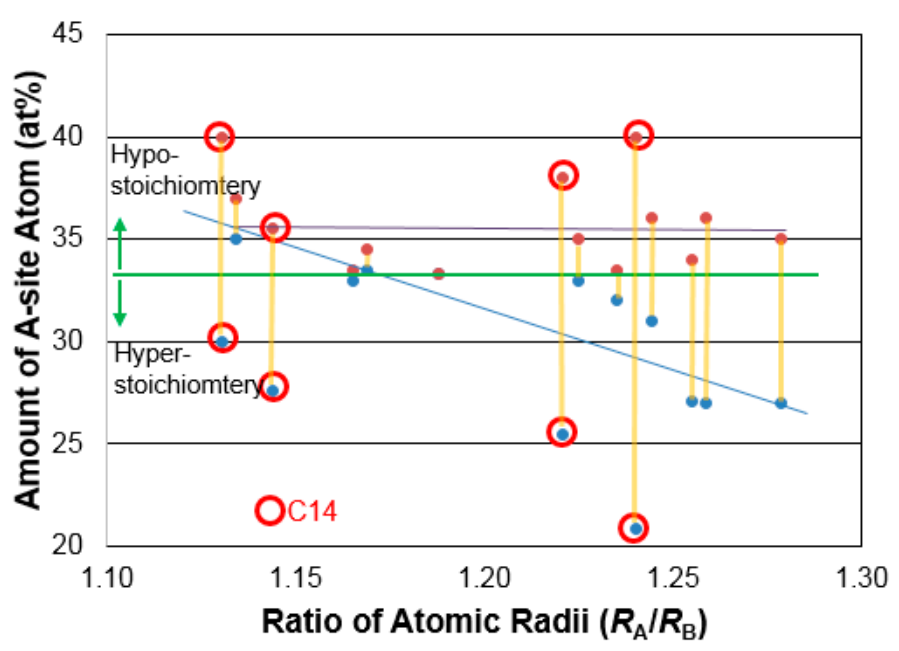

Figure 15. Plot of solubility (composition range) vs. ratio of atomic radii between A-site and B-site atoms from $\mathrm{Ti}, \mathrm{Zr}$, Hf-based Laves phase intermetallic compounds (IMCs). Red and blue dots are the upper and lower bounds of the $\mathrm{AB}_{2}$ soluble range (yellow vertical line) in the composition. Data points in red circles are from $\mathrm{C} 14$ phases and other unmarked data points are from C15 phases.

\subsection{Stoichiometric Alloy}

The stoichiometric $\mathrm{C} 14 \mathrm{MH}$ alloys with a $\mathrm{B} / \mathrm{A}$ ratio close to 2.0 have the highest electrochemical capacity and surface exchange current, and the smallest PCT hysteresis (least pulverization) [256] and is the most studied alloy stoichiometry in the field of battery applications. 


\subsection{Hypo-Stoichiometry}

A C14 alloy with a B/A ratio below 2.0 is a hypo-stoichiometric IMC. The relatively low B/A ratio promotes the occurrence of $\mathrm{AB}$ phase (typically TiNi with a $\mathrm{B} 2$ structure) and improves activation behavior [256]. In a MS + annealing sample, the additional Ti (hypo-stoichiometry) increases both the capacity and cycle life of the electrode [64]. In a gaseous phase study of a $\mathrm{TiCr}$ based C14 alloy, a hypo-stoichiometry ratio (B/A of 1.8) gave the highest H-storage capacity [211].

\subsection{Hyper-Stoichiometry}

A hyper-stoichiometric C14 alloy has a B / A ratio higher than 2.0 and shows a high HRD [151,256], a high open-circuit voltage (from a higher PCT hydrogen equilibrium pressure) [256], and a flat PCT plateau [256]. The hyper-stoichiometric alloy also shows an improved cycle life, due to increased mechanical stability during cycling $[185,258]$. As $x$ increases in a series of hyper-stoichiometric alloys $\mathrm{AB}_{x}(x=2-6)$, the bcc phase abundance increases, and results in improvements in capacity, kinetics [259], and cycle stability [260].

\section{Discussions}

The Ovonic Battery Company (Troy, MI, USA) focused on research about $\mathrm{AB}_{2} \mathrm{MH}$ alloys for $\mathrm{Ni} / \mathrm{MH}$ battery applications for more than three decades before being acquired by BASF (Ludwigshafen, Germany) in 2012. Throughout the years, we witnessed changing market demands and the corresponding reaction from the research communities. Before the successful debut of the commercialized $\mathrm{Ni} / \mathrm{MH}$ battery in 1988 , two main hurdles of the $\mathrm{AB}_{2} \mathrm{MH}$ alloy were slow activation and poor cycle stability. While the former was addressed by fluorination and hot alkaline baths, the latter was improved substantially by composition modifications, mainly the introduction of $\mathrm{Cr}$ and consequent bcc secondary phase. The challenge to the first generation $\mathrm{AB}_{2}$-made $\mathrm{Ni} / \mathrm{MH}$ battery was the self-discharge and was solved by the combination of $\mathrm{V}$-free alloys and the use of the sulfonated separator. At that stage, $\mathrm{AB}_{2} \mathrm{MH}$ alloys were successfully used in products made by Hitachi-Maxell (Tokyo, Japan), Gold-peak (Hong Kong, China), and General Motors (Detroit, MI, USA). With the cheap misch-metal (main raw material for the rival $\mathrm{AB}_{5} \mathrm{MH}$ alloy) available from China, $\mathrm{AB}_{2} \mathrm{MH}$ alloys started to phase out from the consumer market at the turn of the century. Later, the upset of RE prices in 2010 created opportunities for $\mathrm{AB}_{2} \mathrm{MH}$ alloys. However, the bar to enter the market has not been raised in favor of $\mathrm{AB}_{2}$, mostly in the high-rate dischargeability requirement for $\mathrm{HEV}$ and power tools. The superlattice alloy used by FDK (Tokyo, Japan), Panasonic (Osaka, Japan), and Kawasaki Heavy Industry (Tokyo, Japan) became a strong competitor with a capacity between $\mathrm{AB}_{2}$ and $\mathrm{AB}_{5}$, but better high-rate performance. $\mathrm{Mg}$, an indispensable element in the superlattice alloy, makes it more vulnerable to $\mathrm{KOH}$ electrolyte attack, but was mitigated using surfactant additives in the negative electrode paste [44]. The structure of the superlattice allows the removal of $\mathrm{Mn}$ and Co from the composition and improves the charge-retention characteristics tremendously [261]. At the current stage, $\mathrm{AB}_{2}$ has a hard time competing with $\mathrm{AB}_{5}$ in term of price and superlattice alloys in terms of performance.

However, new opportunities started to appear when the conventional $\mathrm{Ni} / \mathrm{MH}$ battery based on the RE-based $\mathrm{AB}_{5}$ or $\mathrm{A}_{2} \mathrm{~B}_{7}$ alloy lost the battle against the rival Li-ion technology. New applications require greater performance improvement in certain areas. For example, a solid-state battery with a thin solid separator [262] and ultra-high-power application with a very thin separator require a spherical MH alloy shape, which can be produced using GA techniques. Superlattice alloy with $\mathrm{Mg}$ inside cannot tolerate the Mg-vaporization because of the large surface area of the powder produced in the GA process, whereas GA with an associated annealing process already been successfully developed for $\mathrm{AB}_{2} \mathrm{MH}$ alloy [62]. The battery / fuel cell combination requires a $\mathrm{MH}$ alloy operated at intermediate temperature range $\left(200-250^{\circ} \mathrm{C}\right)$ [263]. The other opportunity is in stationary applications that require tolerance in the environment of above $50{ }^{\circ} \mathrm{C}[3,4,264]$. While the RE-containing $\mathrm{AB}_{5}$ and 
$\mathrm{A}_{2} \mathrm{~B}_{7} \mathrm{MH}$ alloys form an impeccable surface oxide in the high-temperature environment, the transition metal-based $\mathrm{AB}_{2} \mathrm{MH}$ alloys leach out at a higher speed and are totally controllable by the composition re-adjustment. In the case of the new start-stop automobile application, a low-temperature cranking power is desperately needed [265]. There are a few elements contributing to the low-temperature performance of $\mathrm{AB}_{2} \mathrm{MH}$ alloys through different mechanisms, for example, $\mathrm{Y}$ for surface area increase, $\mathrm{La}, \mathrm{Pd}$ and Mo for surface catalytic ability improvement, and Fe for the increase of beneficial TiNi secondary phase. The pouch cell design (like commercially available Li-ion battery for cell phones) of $\mathrm{Ni} / \mathrm{MH}$ battery operating under a flooded electrolyte configuration requires new $\mathrm{MH}$ alloys with a very low plateau pressure and a highly electrochemically catalytic surface $[266,267]$. The last example is the need for new high-capacity MH alloys that fully utilize the wide voltage window of the newly developed ionic liquid electrolyte [268]. The new chemical environment (electrolyte interface) and lifting of voltage constraint (from competition of hydrogen evolution) present new challenges (i.e., opportunities) for the development of new MH alloys. Although the function of each modifying element in specific areas has been studied and reported in the current work, combinations and the accompanying synergetic effects among these elements have not been reported. Therefore, a review like the current work only provides a guideline for future research. Readers are encouraged to use the results of this study to pursue further performance improvements in C14 Laves phase based MH alloys.

\section{Conclusions}

The main advantages of C14 Laves phase based metal hydride alloys are higher capacities and flexibilities in composition, stoichiometry, and constituent phases, which allow fine tailoring in the electrochemical performance to meet the demands of different applications. Decades of research in this area have already solved historical hurdles in C14-based alloys, such as slow activation, low cycle life, high self-discharge, and poor low-temperature performance. To face the new challenges from future applications, we have compiled comprehensive comparisons of preparation methods, alloy property requirements, the pros and cons of each constituting/modifying element, and choice of stoichiometry in the current study. Based on these previous works, new directions for additional improvement in the electrochemical performance should focus on the combination of modifier elements with different functions.

Acknowledgments: The authors would like to thank the following individuals from BASF-Ovonic making contributions to the ongoing research in $\mathrm{AB}_{2} \mathrm{MH}$ alloys: Michael A. Fetcenko, Taihei Ouchi, Jean Nei, Diana F. Wong, Benjamin Reichman, Sherry Hu, John Koch, Suiling Chen, Cheryl Setterington, David Pawlik, Allen Chan, and Ryan J. Blankenship and former employees of Ovonics: Marvin Siskind, Su Cronogue, Jun Im, Joseph Tribu, Timothy Gizinski, David Smith, Xiaorong Tang, Crystal Yeh, Aereon Bisel, Anna Lewis, Lixin Wang, Tiejun Meng, Baoquan Huang, Feng Li, Melanie Reinhout, Nan Yu, Betty Cai, and Benjamin Chao for their technical assistance and valuable contributions. Kwo-Hsiung Young is obligated to his long-time partners in research: Ronald Tsang from Gold Peak, Koichi Morii from Daido Steel, Shigekazu Yasuoka from FDK Co., Leonid A. Bendersky from the National Institute of Standards and Technology, and Simon Ng from Wayne State University.

Author Contributions: Kwo-Hsiung Young prepared the main text and photographs. Shiuan Chang and Xinting Lin helped in the preparation of manuscript.

Conflicts of Interest: The authors declare no conflict of interest.

\section{Abbreviations}

The following abbreviations are used in this manuscript:

$\begin{array}{ll}\mathrm{Ni} / \mathrm{MH} & \text { Nickel/metal hydride } \\ \mathrm{MH} & \text { Metal hydride } \\ \text { H-storage } & \text { Hydrogen-strorage } \\ \text { VIM } & \text { Vacuum induction melting } \\ \mathrm{AM} & \text { Arc melting }\end{array}$




$\begin{array}{ll}\text { CC } & \text { Centrifugal casting } \\ \text { MS } & \text { Melt spinning } \\ \text { GA } & \text { Gas atomization } \\ \text { MA } & \text { Mechannical alloying } \\ \text { PS } & \text { Plasma spray } \\ \text { SEM } & \text { Scanning electron microscope } \\ \text { bcc } & \text { Bady-centered cubic } \\ \text { HRD } & \text { High-rate dischargeability } \\ \text { M-H } & \text { metal-hydrogen } \\ \text { RE } & \text { Rare-earth elements } \\ \text { PCT } & \text { Pressure-concomposition-temperature } \\ \text { EV } & \text { Electric vehicle } \\ \text { HEV } & \text { Hybrid electric vehicle } \\ \text { N/P } & \text { Negative/Positive } \\ \text { HIA } & \text { Hydrogen-induced amorphization } \\ \text { IMC } & \text { Intermettalic compound } \\ \text { TEM } & \text { Transmission electron microscope }\end{array}$

\section{References}

1. Cai, X.; Young, K.; Chang, S. Reviews on the Chinese Patent regarding nickel/metal hydride battery. Batteries 2017, 3, 24. [CrossRef]

2. Ogawa, K. Toyota to Start Local Production of NiMH Battery Cells in China by End of 2016. Available online: http:/ /techon.nikkeibp.co.jp/atclen/news_en/15mk/030900433/ (accessed on 2 November 2016).

3. Zelinsky, M.; Koch, J.; Fetcenko, M. Heat Tolerant NiMH Batteries for Stationary Power. Available online: www.battcon.com/PapersFinal2010/ZelinskyPaper2010Final_12.pdf (accessed on 28 March 2016).

4. Zelinsky, M.; Koch, J. Batteries and Heat-A Recipe for Success? Available online: www.battcon.com/ PapersFinal2013/16-Mike\%20Zelinsky\%20-\%20Batteries\%20and\%20Heat.pdf (accessed on 28 March 2016).

5. Teraoka, H. Development of Ni-MH ESS with Lifetime and Performance Estimation Technology. In Proceedings of the 34th International Battery Seminar \& Exhibit, Fort Lauderdale, FL, USA, 20-23 March 2017.

6. Teraoka, H. Ni-MH Stationary Energy Storage: Extreme Temperature \& Long Life Developments. In Proceedings of the 33th International Battery Seminar \& Exhibit, Fort Lauderdale, FL, USA, 21-24 March 2016.

7. Teraoka, H. Development of Highly Durable and Long Life Ni-MH Batteries for Energy Storage Systems. In Proceedings of the 32th International Battery Seminar \& Exhibit, Fort Lauderdale, FL, USA, 9-12 March 2015.

8. Young, K.; Ouchi, T.; Nei, J.; Yasuoka, S. Fe-substitution for Ni in misch metal-based superlattice hydrogen absorbing alloys-Part 1. Structural, hydrogen storage, and electrochemical properties. Batteries 2016, 2, 34. [CrossRef]

9. Kai, T.; Ishida, J.; Yasuoka, S.; Takeno, K. The Effect of Nickel-Metal Hydride Battery's Characteristics with Structure of the Alloy. In Proceedings of the 54th Battery Symposium, Osaka, Japan, 7-9 October 2013; p. 210.

10. Fetcenko, M.A.; Ovshinsky, S.A.; Young, K.; Reichman, B.; Fierro, C.; Koch, J.; Martin, F.; Mays, W.; Ouchi, T.; Sommers, B.; et al. High catalytic activity disordered VTiZrNiCrCoMnAlSn hydrogen storage alloys for nickel-metal hydride batteries. J. Alloys Compd. 2002, 330, 752-759. [CrossRef]

11. Young, K.; Ouchi, T.; Koch, J.; Fetcenko, M.A. The role of Mn in C14 Laves phase multi-component alloys for NiMH battery application. J. Alloys Compd. 2009, 477, 749-758. [CrossRef]

12. Young, K.; Yasuoka, S. Past, Present, and Future of Metal Hydride Alloys in Nickel-Metal Hydride Batteries. In Proceedings of the MH2014 Conference, Salford, UK, 20-25 July 2014.

13. Chang, S.; Young, K.; Nei, J.; Fierro, C. Reviews on the U.S. Patents regarding nickel/metal hydride batteries. Batteries 2016, 2, 10. [CrossRef]

14. Young, K.; Nei, J. The current status of hydrogen storage alloy development for electrochemical applications. Materials 2013, 6, 4574-4608. [CrossRef] [PubMed]

15. Feng, F.; Geng, M.; Northwood, D.O. Electrochemical behaviour of intermetallic-based metal hydrides used in $\mathrm{Ni}$ /metal hydride (MH) batteries: A review. Int. J. Hydrogen Energy 2001, 26, 725-734. [CrossRef] 
16. Kleperis, J.; Wójcik, G.; Czerwinski, A.; Skowronski, J.; Kopxzyk, M.; Beltowska-Brzezinska, M. Electrochemical behavior of metal hydrides. J. Solid State Electrochem. 2001, 5, 229-249. [CrossRef]

17. Han, S.; Zhao, M.; Wu, L.; Zheng, Y. Effect of additive elements on electrochemical properties of $\mathrm{AB}_{2}$-type Laves phase alloys. Chem. J. Chin. Univ. 2003, 24, 2256-2259. (In Chinese)

18. Wang, J.; Yu, R.; Liu, Q. Effects of alloying side B on Ti-based $\mathrm{AB}_{2}$ hydrogen storage alloys. J. Harbin Inst. Technol. (New Ser.) 2004, 11, 485-492.

19. Zhao, X.; Ma, L. Recent progress in hydrogen storage alloys for nickel/metal hydride secondary batteries. Int. J. Hydrogen Energy 2009, 34, 4788-4796. [CrossRef]

20. Ouyang, L.; Huang, J.; Wang, H.; Liu, J.; Zhu, M. Progress of hydrogen storage alloys for Ni-MH rechargeable power batteries in electric vehicles: A review. Mater. Chem. Phys. 2017, 200, 164-178. [CrossRef]

21. Stein, F.; Palm, M.; Sauthoff, G. Structure and stability of Laves phases. Part I. Critical assessment of factors controlling Laves phase stability. Intermetallics 2011, 12, 713-720. [CrossRef]

22. Kumar, K.S.; Hazzledine, P.M. Polytypic transformations in Laves phases. Intermetallics 2004, 12, 763-770. [CrossRef]

23. Chisholm, M.F.; Kumar, S.; Hazzledine, P. Dislocations in complex materials. Sciences 2005, 307, 701-703. [CrossRef] [PubMed]

24. Baumann, W.; Leineweber, A.; Mittemeijer, E.J. The kinetics of a polytypic Laves phase transformation in $\mathrm{TiCr}_{2}$. Intermetallics 2011, 19, 526-535. [CrossRef]

25. Scudino, S.; Donnadieu, P.; Surreddi, K.B.; Nikolowski, K.; Stoica, M.; Eckert, J. Microstructure and mechanical properties of Laves phase-reinforced $\mathrm{Fe}-\mathrm{Zr}-\mathrm{Cr}$ alloys. Intermetallics 2009, 17, 532. [CrossRef]

26. Abraham, D.P.; Richardson, J.W., Jr.; McDeavitt, S.M. Laves intermetallics in stainless steel-zirconium alloys. Mater. Sci. Eng. A 1997, 239-240, 658-664. [CrossRef]

27. Young, K.; Nei, J.; Wan, C.; Yartys, V. Comparison of C14- and C15-predominated $\mathrm{AB}_{2}$ metal hydride alloys for electrochemical applications. Batteries 2017, 3, 22. [CrossRef]

28. Laves Crystal Structure of Laves Phase. Available online: http://www.geocities.jp/ohba_lab_ob_page/ structure5.html (accessed on 26 April 2017).

29. Young, K. Metal Hydride. In Elsevier Reference Module in Chemistry, Molecular Sciences and Chemical Engineering; Reedijk, J., Ed.; Elsevier: Waltham, MA, USA, 2013.

30. Joubert, J.-M.; Latroche, M.; Percheron-Guégan, A.; Bouet, J. Improvement of the electrochemical activity of $\mathrm{Zr}-\mathrm{Ni}-\mathrm{Cr}$ Laves phase hydride electrodes by secondary phase precipitation. J. Alloys Compd. 1996, 240, 219-228. [CrossRef]

31. Lee, H.-H.; Lee, K.-Y.; Lee, J.-Y. The hydrogenation characteristics of Ti-Zr-V-Mn-Ni C14 type Laves phase alloys for metal hydride electrodes. J. Alloys Compd. 1997, 253, 601-604. [CrossRef]

32. Shu, K.Y.; Lei, Y.Q.; Yang, X.G.; Zhang, S.K.; Chen, L.S.; Lu, G.L.; Wang, Q.D. A comparative study on the electrochemical performance of rapidly solidified and conventionally cast hydride electrode alloy $\mathrm{Zr}(\mathrm{NiMnM})_{2.1}$. J. Alloys Compd. 1999, 290, 124-128. [CrossRef]

33. Chen, L.; Wu, F.; Tong, M.; Chen, D.M.; Long, R.B.; Shang, Z.Q.; Liu, H.; Sun, W.S.; Yang, Y.; Wang, L.B.; et al. Advanced nanocrystalline $\mathrm{Zr}$-based $\mathrm{AB}_{2}$ hydrogen storage electrode materials for $\mathrm{NiMH} E V$ batteries. J. Alloys Compd. 1999, 293, 508-520. [CrossRef]

34. Zhu, Y.; Liu, Y.; Hua, F.; Li, L. Effect of rapid solidification on the structural and electrochemical properties of the Ti-V-based hydrogen storage electrode alloy. J. Alloys Compd. 2008, 463, 528-532. [CrossRef]

35. Huang, S.S.; Chuang, H.J.; Chan, S.L.I. Effects of fluorination on the hydriding and electrochemical properties of a gas-atomized Zr-based hydrogen storage alloy. J. Alloys Compd. 2002, 330, 617-621. [CrossRef]

36. Kim, J.H.; Lee, H.; Hwang, K.T.; Han, J.S. Hydriding behavior in $\mathrm{Zr}$-based $\mathrm{AB}_{2}$ alloy by gas atomization process. Int. J. Hydrogen Energy 2009, 34, 9424-9430. [CrossRef]

37. Jung, C.B.; Lee, K.S. Electrode characteristics of metal hydride electrodes prepared by mechanical alloying. J. Alloys Compd. 1997, 253, 605-608. [CrossRef]

38. Qiu, S.J.; Chu, H.L.; Zhang, Y.; Sun, L.X.; Xu, F.; Cao, Z. The electrochemical performances of Ti-V-based hydrogen storage composite electrodes prepared by ball milling method. Int. J. Hydrogen Energy 2008, 33, 7471-7478. [CrossRef]

39. Kazemipour, M.; Salimijazi, H.; Saidi, A.; Saatchi, A. Hydrogen storage properties of $\operatorname{Ti}_{0.72} \mathrm{Zr}_{0.28} \mathrm{Mn}_{1.6} \mathrm{~V}_{0.4}$ alloy prepared by mechanical alloying and copper boat induction melting. Int. J. Hydrogen Energy 2014, 39, 12784-12788. [CrossRef] 
40. Kazemipour, M.; Salimijazi, H.; Saidi, A.; Saatchi, A.; Mostaghimi, J.; Pershin, L. The electrochemical hydrogen storage properties of $\mathrm{Ti}_{0.72} \mathrm{Zr}_{0.28} \mathrm{Mn}_{1.6} \mathrm{~V}_{0.4}$ alloy synthesized by vacuum plasma spraying and vacuum copper boat induction melting: A comparative study. Int. J. Hydrogen Energy 2015, 40, 15569-15577. [CrossRef]

41. Young, K.; Fetcenko, M.A.; Li, F.; Ouchi, T. Structural, thermodynamic, and electrochemical properties of $\mathrm{Ti}_{\mathrm{x}} \mathrm{Zr}_{1-\mathrm{x}}(\mathrm{VNiCrMnCoAl})_{2} \mathrm{C} 14$ Laves phase alloys. J. Alloys Compd. 2008, 464, 238-247. [CrossRef]

42. Izumi, Y.; Moriwaki, Y.; Yamashita, K.; Tokuhiro, T. Nickel-Metal Hydride Storage Battery and Alloy for Configuring Negative Electrode of the Same. U.S. Patent 5,962,156, 5 October 1999.

43. Young, K.; Koch, J.; Ouchi, T.; Banik, A.; Fetcenko, M.A. Study of $\mathrm{AB}_{2}$ alloy electrodes for Ni/MH battery prepared by centrifugal casting and gas atomization. J. Alloys Compd. 2010, 496, 669-677. [CrossRef]

44. Ouchi, T.; Young, K.; Moghe, D. Reviews on the Japanese Patent Applications regarding nickel/metal hydride batteries. Batteries 2016, 2, 21. [CrossRef]

45. Young, K. Stoichiometry in inter-metallic compounds for hydrogen storage applications. In Stoichiometry and Materials Science-When Numbers Matter; Innocenti, A., Kamarulzaman, N., Eds.; InTech: Rijeka, Crotia, 2012.

46. Humana, R.M.; Thomas, J.E.; Ruiz, F.; Real, S.G.; Castro, E.B.; Visintin, A. Electrochemical behavior of metal hydride electrode with different particle size. Int. J. Hydrogen Energy 2012, 37, 14966-14971. [CrossRef]

47. Matsuoka, M.; Tamura, K. Effects of mechanical modification on electrochemical performance of Zr-Ti-based Laves-phase alloy electrode. J. Electrochem. Soc. 2007, 154, A119-A122. [CrossRef]

48. Fetcenko, M.A.; Kaatz, T.; Sumner, S.P.; LaRocca, J. Hydride Reactor Apparatus for Hydrogen Comminution of Metal Hydride Hydrogen Storage Materials. U.S. Patent 4,893,756, 16 January 1990.

49. Young, K.; Fetcenko, M.A. Method for Powder Formation of a Hydrogen Storage Alloy. U.S. Patent 6,120,936, 19 September 2000.

50. Kim, D.M.; Lee, H.; Cho, K.; Lee, J.Y. Effect of $\mathrm{Cu}$ powder as an additive material on the inner pressure of a sealed-type $\mathrm{Ni}-\mathrm{MH}$ rechargeable battery using a Zr-based alloy as an anode. J. Alloys Compd. 1999, 282, 261-267. [CrossRef]

51. Tan, S.; Shen, Y.; Şahin, E.O.; Noréus, D.; Öztürk, T. Activation behavior of an $\mathrm{AB}_{2}$ type metal hydride alloy for NiMH batteries. Int. J. Hydrogen Energy 2016, 41, 9948-9953. [CrossRef]

52. Liu, B.H.; Li, Z.P.; Okutsu, A.; Suda, S. A wet ball milling treatment of Zr-based $\mathrm{AB}_{2}$ alloys as negative electrode materials. J. Alloys Compd. 2000, 296, 148-151. [CrossRef]

53. Great Powder Website. Available online: http:/ / www.greatpowder.com/yingwen/ (accessed on 10 May 2017).

54. Higuchi, E.; Li, Z.P.; Suda, S.; Nohara, S.; Inoue, H.; Iwakura, C. Structural and electrochemical characterization of fluorinated $\mathrm{AB}_{2}$-type Laves phase alloys obtained by different pulverization methods. J. Alloys Compd. 2002, 335, 241-245. [CrossRef]

55. Hu, W.K.; Kim, D.M.; Jeon, S.W.; Lee, J.Y. Effect of annealing treatment on electrochemical properties of Mm-based hydrogen storage alloys for Ni/MH batteries. J. Alloys Compd. 1998, 270, 255-264. [CrossRef]

56. Young, K.; Nei, J.; Ouchi, T.; Fetcenko, M.A. Phase abundances in $\mathrm{AB}_{2}$ metal hydride alloys and their correlations to various properties. J. Alloys Compd. 2011, 509, 2277-2284. [CrossRef]

57. Young, K.; Ouchi, T.; Meng, T.; Wong, D.F. Studies on the synergetic effects in multi-phase metal hydride alloys. Batteries 2016, 2, 15. [CrossRef]

58. Züttel, A.; Meli, F.; Chartouni, D.; Schlapbach, L.; Lichtenberg, F.; Friedrich, B. Properties of $\mathrm{Zr}\left(\mathrm{V}_{0.25} \mathrm{Ni}_{0.75}\right)_{2}$ metal hydride as active electrode material. J. Alloys Compd. 1996, 239, 175-282. [CrossRef]

59. Zhang, Q.A.; Lei, Y.Q.; Yang, X.G.; Ren, K.; Wang, Q.D. Annealing treatment of $\mathrm{AB}_{2}$-type hydrogen storage alloys: I. crystal structures. J. Alloys Compd. 1999, 292, 236-240. [CrossRef]

60. Zhang, Q.A.; Lei, Y.Q.; Yang, X.G.; Du, Y.L.; Wang, Q.D. Effects of annealing treatment on phase structures, hydrogen absorption-desorption characteristics and electrochemical properties of a $\mathrm{V}_{3} \mathrm{TiNi}_{0.56} \mathrm{Hf}_{0.24} \mathrm{Mn}_{0.15} \mathrm{Cr}_{0.1}$ alloy. J. Alloys Compd. 2000, 305, 125-129. [CrossRef]

61. Young, K.; Ouchi, T.; Huang, B.; Chao, B.; Fetcenko, M.A.; Bendersky, L.A.; Wang, K.; Chiu, C. The correlation of $\mathrm{C} 14 / \mathrm{C} 15$ phase abundance and electrochemical properties in the $\mathrm{AB}_{2}$ alloys. J. Alloys Compd. 2010, 506, 841-848. [CrossRef]

62. Young, K.; Ouchi, T.; Banik, A.; Koch, J.; Fetcenko, M.A. Improvement in the electrochemical properties of gas atomized $\mathrm{AB}_{2}$ metal hydride alloys by hydrogen annealing. Int. J. Hydrogen Energy 2011, 36, 3547-3555. [CrossRef] 
63. Chuang, H.J.; Huang, S.S.; Ma, C.Y.; Chan, S.L.I. Effect of annealing heat treatment on an atomized $\mathrm{AB}_{2}$ hydrogen storage alloy. J. Alloys Compd. 1999, 285, 284-291. [CrossRef]

64. Liu, H.; Li, R. Effect of variation of constituent on microstructure and electrochemical properties of $\mathrm{AB}_{2}$ hydrogen storage alloys. Foundry Technol. 2007, 29, 179-183. (In Chinese)

65. Klein, B.; Simon, N.; Klyamkine, S.; Latroche, M.; Percheron-Guégan, A. Improvement of the thermodynamical and electrochemical properties of multicomponent Laves phase hydrides by thermal annealing. J. Alloys Compd. 1998, 280, 284-289. [CrossRef]

66. Züttel, A.; Meli, F.; Schlapbach, L. Effects of pretreatment on the activation behavior of $\mathrm{Zr}\left(\mathrm{V}_{0.25} \mathrm{Ni}_{0.75}\right)_{2} \mathrm{metal}$ hydride electrodes in alkaline solution. J. Alloys Compd. 1994, 209, 99-105. [CrossRef]

67. Liu, F.J.; Kitayama, K.; Suda, S. La and Ce-incorporation effects on the surface properties of the fluorinated $(\mathrm{Ti}, \mathrm{Xr})(\mathrm{Mn}, \mathrm{Cr}, \mathrm{Ci})_{2}$ hydriding alloys. Vacuum 1996, 47, 903-906. [CrossRef]

68. Liu, B.H.; Li, Z.P.; Higuchi, E.; Suda, S. Improvement of the electrochemical properties of Zr-based $\mathrm{AB}_{2}$ alloys by an advanced fluorination technique. J. Alloys Compd. 1999, 293, 702-706. [CrossRef]

69. Li, Z.P.; Higuchi, E.; Liu, B.H.; Suda, S. Effects of fluorination temperature on surface structure and electrochemical properties of $\mathrm{AB}_{2}$ electrode alloys. Electrochim. Acta 2000, 45, 1773-1779. [CrossRef]

70. Park, H.Y.; Cho, W.I.; Cho, B.W.; Lee, S.R.; Yun, K.S. Effect of fluorination on the lanthanum-doped $\mathrm{AB}_{2}$-type metal hydride electrodes. J. Power Sources 2001, 92, 149-156. [CrossRef]

71. Li, Z.P.; Liu, B.H.; Hitaka, K.; Suda, S. Effects of surface structure of fluorinated $\mathrm{AB}_{2}$ alloys on their electrodes and battery performances. J. Alloys Compd. 2002, 330, 776-781. [CrossRef]

72. Young, K.H.; Fetcenko, M.A.; Ovshinsky, S.R.; Ouchi, T.; Reichman, B.; Mays, W.C. Improved surface catalysis of $\mathrm{Zr}$-based Laves phase alloys for NiMH batteries. In Hydrogen at Surface and Interfaces; Jerkiewicz, G., Feliu, J.M., Popov, B.N., Eds.; Electrochemical Society: Pennington, NJ, USA, 2000.

73. Reichman, B.; Venkatesan, S.; Fetcenko, M.A.; Jeffries, K.; Stahl, S.; Bennett, C. Activated Rechargeable Hydrogen Storage Electrode and Method. U.S. Patent 4,716,088, 29 December 1987.

74. Jung, J.H.; Liu, B.H.; Lee, J.Y. Activation behavior of $\mathrm{Zr}_{0.7} \mathrm{Ti}_{0.3} \mathrm{Cr}_{0.3} \mathrm{Mn}_{0.3} \mathrm{~V}_{0.4} \mathrm{Ni}$ alloy electrode modified by the hot-charging treatment. J. Alloys Compd. 1998, 264, 306-310. [CrossRef]

75. Liu, B.; Jung, J.; Lee, H.; Lee, K.; Lee, J. Improved electrochemical performance of $\mathrm{AB}_{2}$-type metal hydride electrode activated by the hot-charging process. J. Alloys Compd. 1996, 245, 132-141. [CrossRef]

76. Cao, J.; Gao, X.; Lin, D.; Zhou, X.; Yuan, H.; Song, D.; Shen, P. Activation behavior of the Zr-based Laves phase alloy electrode. J. Power Sources 2011, 93, 141-144.

77. Şahin, E.O. Development of Rare Earth-Free Negative Electrode Materials for NiMH Batteries. In Proceeding of the 18th International Metallurgy \& Materials Congress, Istanbul, Turkey, 29 September-1 October 2016; pp. 770-773.

78. Jung, J.H.; Lee, H.H.; Kim, D.M.; Jang, K.J.; Lee, J.Y. Degradation behavior of Cu-coated Ti-Zr-V-Mn-Ni metal hydride electrodes. J. Alloys Compd. 1998, 266, 266-270. [CrossRef]

79. Sun, D.; Latroche, M.; Percheron-Guégan, A. Activation behaviour of mechanically Ni-coated Zr-based laves phase hydride electrode. J. Alloys Compd. 1997, 257, 302-305. [CrossRef]

80. Jurczyk, M.; Rajewski, W.; Majchrzycki, W.; Wojcik, G. Synthesis and electrochemical properties of high-energy ball-milled Laves phase (Zr,Ti)(V,Mn,Cr) 2 alloys with nickel powder. J. Alloys Compd. 1998, 274, 299-302. [CrossRef]

81. Lee, S.; Lee, H.; Yu, J.S.; Fateev, G.A.; Lee, J.Y. The activation characteristics of a Zr-based hydrogen storage alloy electrode surface-modified by ball-milling process. J. Alloys Compd. 1999, 292, 258-265. [CrossRef]

82. Li, S.; Zhao, M.; Wang, Y.; Zhai, J. Structure and electrochemical property of ball-milled $\mathrm{Ti}_{0.26} \mathrm{Zr}_{0.07} \mathrm{Mn}_{0.1}$ $\mathrm{Ni}_{0.33} \mathrm{~V}_{0.24}$ alloy. Mater. Chem. Phys. 2009, 118, 51-56. [CrossRef]

83. Chu, H.L.; Zhang, Y.; Sun, L.X.; Qiu, S.J.; Qi, Y.N.; Xu, F.; Yuan, H. Structure and electrochemical properties of composite electrodes synthesized by mechanical milling Ni-free TiMn 2 -based alloy with La-based alloy. J. Alloys Compd. 2007, 446-447, 614-619. [CrossRef]

84. Li, P.; Wang, X.; Wu, J.; Zhao, W.; Li, R.; Ma, N. Present status on research of $\mathrm{AB}_{2}$-type Laves phase hydrogen storage electrode materials. Met. Funct. Mater. 2000, 7, 7-12. (In Chinese)

85. Young, K. Electrochemical applications of metal hydride. In Compendium of Hydrogen Energy Volume 3: Hydrogen Energy Conversion; Barbir, F., Basile, A., Veziroglu, T.N., Eds.; Woodhead Publishing: Cambridge, UK, 2016. 
86. Hong, K. The development of hydrogen storage alloys and the progress of nickel hydride batteries. J. Alloys Compd. 2001, 321, 307-313. [CrossRef]

87. Young, K.; Huang, B.; Regmi, R.K.; Lawes, G.; Liu, Y. Comparisons of metallic clusters imbedded in the surface oxide of $\mathrm{AB}_{2}, \mathrm{AB}_{5}$, and $\mathrm{A}_{2} \mathrm{~B}_{7}$ alloys. J. Alloys Compd. 2010, 506, 831-840. [CrossRef]

88. Young, K.; Ouchi, T.; Fetcenko, M.A. Pressure-composition-temperature hysteresis in C14 Laves phase alloys: Part 1. Simple ternary alloys. J. Alloys Compd. 2009, 480, 428-433. [CrossRef]

89. Young, K.; Ouchi, T.; Mays, W.; Reichman, B.; Fetcenko, M.A. Pressure-composition-temperature hysteresis in C14 Laves phase alloys: Part 2. Applications in NiMH batteries. J. Alloys Compd. 2009, 480, 434-439. [CrossRef]

90. Young, K.; Yasuoka, S. Capacity degradation mechanisms in nickel/metal hydride batteries. Batteries 2016, 2, 3. [CrossRef]

91. Knosp, B.; Vallet, L.; Blanchard, P. Performance of an $\mathrm{AB}_{2}$ alloy in sealed Ni-MH batteries for electric vehicles: Quantification of corrosion rate and consequences on the battery performance. J. Alloys Compd. 1999, 293, 770-774. [CrossRef]

92. Young, K.; Wong, D.F.; Yasuoka, S.; Ishida, J.; Nei, J.; Koch, J. Different failure modes for V-containing and V-free $\mathrm{AB}_{2}$ metal hydride alloys. J. Power Sources 2014, 251, 170-177. [CrossRef]

93. Fetcenko, M.A.; Ovshinsky, S.R.; Reichman, B.; Young, K.; Fierro, C.; Koch, J.; Zallen, A.; Mays, W.; Ouchi, T. Recent advances in NiMH battery technology. J. Power Sources 2007, 165, 544-551. [CrossRef]

94. Young, K.; Chao, B.; Liu, Y.; Nei, J. Microstructures of the oxides on the activated $\mathrm{AB}_{2}$ and $\mathrm{AB}_{5}$ metal hydride alloys surface. J. Alloys Compd. 2014, 606, 97-104. [CrossRef]

95. Young, K.; Chao, B.; Pawlik, D.; Shen, H.T. Transmission electron microscope studies in the surface oxide on the La-containing $\mathrm{AB}_{2}$ metal hydride alloy. J. Alloys Compd. 2016, 672, 356-365. [CrossRef]

96. Zhu, Y.; Pan, H.; Gao, M.; Liu, Y.; Li, R.; Lei, Y.; Wang, Q. Degradation mechanisms of Ti-V-based multiphase hydrogen storage alloy electrode. Int. J. Hydrogen Energy 2004, 29, 313-318. [CrossRef]

97. Liu, B.H.; Li, Z.P.; Matsuyama, Y.; Kitani, R.; Suda, S. Corrosion and degradation behavior of Zr-based $\mathrm{AB}_{2}$ alloy electrodes during electrochemical cycling. J. Alloys Compd. 2000, 296, 201-208. [CrossRef]

98. Chuang, H.J.; Chan, S.L.I. Study of the performance of Ti-Zr based hydrogen storage alloys. J. Power Sources 1999, 77, 159-163. [CrossRef]

99. Aoki, K.; Yamamoto, T.; Masumoto, T. Hydrogen induced amorphization in $\mathrm{RNi}_{2}$ laves phases. Scr. Metall. 1987, 21, 27-31. [CrossRef]

100. Aoki, K. Amorphous phase formation by hydrogen absorption. Mater. Sci. Eng. A 2001, 304-306, 45-53. [CrossRef]

101. Aoki, K.; Masumoto, T. Hydrogen-induced amorphization of intermetallics. J. Alloys Compd. 1995, 231, $20-28$. [CrossRef]

102. Züttel, A.; Chartouni, D.; Nützenadel, C.; Gross, K.; Schlapbach, L. Bulk and surface properties of crystalline and amorphous $\mathrm{Zr}_{36}\left(\mathrm{~V}_{0.33} \mathrm{Ni}_{0.66}\right)_{64}$ alloy as active electrode material. J. Alloys Compd. 1998, 266, 321-326. [CrossRef]

103. Hu, W.K.; Zhang, Y.S.; Song, D.Y.; Shen, P.W. Electrochemical hydrogen storage properties of amorphous and crystalline MI-Ni alloy films. Int. J. Hydrogen Energy 1996, 21, 651-656. [CrossRef]

104. Zhao, X.; Ma, L.; Gou, Y.; Shen, X. Structure, morphology and hydrogen desorption characteristics of amorphous and crystalline Ti-Ni alloys. Mater. Sci. Eng. A 2009, 516, 50-53. [CrossRef]

105. Yang, X.; Lei, Y.; Wang, C.; Zhu, G.; Zhang, W.; Wang, Q. Influence of amorphization on electrode performances of $\mathrm{AB}_{2}$ type hydrogen storage alloys. J. Alloys Compd. 1998, 265, 264-268. [CrossRef]

106. Boettinger, W.J.; Newbury, D.E.; Wang, K.; Bendersky, L.A.; Chiu, C.; Kattner, U.R.; Young, K.; Chao, B. Examination of multiphase $(\mathrm{Zr}, \mathrm{Ti})(\mathrm{V}, \mathrm{Cr}, \mathrm{Mn}, \mathrm{Ni})_{2} \mathrm{Ni}-\mathrm{MH}$ electrode alloys: Part I. Dendritic solidification structure. Metall. Mater. Trans. A 2010, 41, 2033-2047. [CrossRef]

107. Bendersky, L.A.; Wang, K.; Boettinger, W.J.; Newbury, D.E.; Young, K.; Chao, B. Examination of multiphase $(\mathrm{Zr}, \mathrm{Ti})(\mathrm{V}, \mathrm{Cr}, \mathrm{Mn}, \mathrm{Ni})_{2} \mathrm{Ni}-\mathrm{MH}$ electrode alloys: Part II. Solid-state transformation of the interdendritic B2 phase. Metall. Mater. Trans. A 2010, 41, 1891-1906. [CrossRef]

108. Liu, Y.; Young, K. Microstructure investigation on metal hydride alloys by electron backscatter Diffraction Technique. Batteries 2016, 2, 26. [CrossRef] 
109. Bendersky, L.A.; Wang, K.; Levin, I.; Newbury, D.; Young, K.; Chao, B.; Creuziger, A. Ti $\operatorname{Ti}_{12.5} \mathrm{Zr}_{21} \mathrm{~V}_{10} \mathrm{Cr}_{8.5}$ $\mathrm{Mn}_{\mathrm{x}} \mathrm{Co}_{1.5} \mathrm{Ni}_{46.5-\mathrm{x}} \mathrm{AB}_{2}$-type metal hydride alloys for electrochemical storage application: Part 1. Structural characteristics. J. Power Sources 2012, 218, 474-486. [CrossRef]

110. Tokunaga, T.; Motsumoto, S.; Ohtani, H.; Hasebe, M. Thermodynamic calculation of phase equilibria in the $\mathrm{Nb-Ni-Ti-Zr} \mathrm{quaternary} \mathrm{system.} \mathrm{Mater.} \mathrm{Trans.} \mathrm{2007,} \mathrm{48,} \mathrm{89-96.} \mathrm{[CrossRef]}$

111. Young, K.; Ouchi, T.; Reichman, B.; Mays, W.; Regmi, R.; Lawes, G.; Fetcenko, M.A.; Wu, A. Optimization of Co-content in C14 Laves phase multi-component alloys for NiMH battery application. J. Alloys Compd. 2010, 489, 202-210. [CrossRef]

112. Young, K.; Reichman, B.; Fetcenko, M.A. Electrochemical performance of $\mathrm{AB}_{2}$ metal hydride alloys measured at $-40{ }^{\circ}$ C. J. Alloys Compd. 2013, 580, S349-S352. [CrossRef]

113. Young, K.; Wong, D.F.; Nei, J.; Reichman, B. Electrochemical properties of hypo-stoichiometric Y-doped $\mathrm{AB}_{2}$ metal hydride alloys at ultra-low temperature. J. Alloys Compd. 2015, 643, 17-27. [CrossRef]

114. Zhang, Q.A.; Lei, Y.Q.; Wang, C.S.; Wang, F.S.; Wang, Q.D. Structure of the secondary phase and its effects on hydrogen-storage properties in a $\mathrm{Ti}_{0.7} \mathrm{Zr}_{0.2} \mathrm{~V}_{0.1} \mathrm{Ni}$ alloy. J. Power Sources 1998, 75, 288-291. [CrossRef]

115. Saldan, I.; Burtovyy, R.; Becker, H.W.; Ader, V.; Wöll, C. Ti-Ni alloys as MH electrodes in Ni-MH accumulators. Int. J. Hydrog. Energy 2008, 33, 7177-7184. [CrossRef]

116. Nei, J.; Young, K. Gaseous phase and electrochemical hydrogen storage properties of $\mathrm{Ti}_{50} \mathrm{Zr}_{1} \mathrm{Ni}_{44} \mathrm{X}_{5}(X=\mathrm{Ni}$, $\mathrm{Cr}, \mathrm{Mn}, \mathrm{Fe}, \mathrm{Co}$, or $\mathrm{Cu}$ ) for nickel metal hydride battery applications. Batteries 2016, 2, 24. [CrossRef]

117. Emami, H.; Cuevas, F.; Latroche, M. Ti(Ni,Cu) pseudobinary compounds as efficient negative electrodes for Ni-MH batteries. J. Power Sources 2014, 265, 182-191. [CrossRef]

118. Shu, K.Y.; Yang, X.G.; Zhang, S.K.; Lü, G.L.; Lei, Y.Q.; Wang, Q.D. Effect of Cr and Co additives on microstructure and electrochemical performance of $\mathrm{Zr}(\mathrm{NiVMn})_{2} \mathrm{M}_{0.1}$ alloys. J. Alloys Compd. 2000, 306, 122-126. [CrossRef]

119. Young, K.; Chao, B.; Bendersky, L.A.; Wang, $\mathrm{K}$. $\mathrm{Ti}_{12.5} \mathrm{Zr}_{21} \mathrm{~V}_{10} \mathrm{Cr}_{8.5} \mathrm{Mn}_{\mathrm{x}} \mathrm{Co}_{1.5} \mathrm{Ni}_{46.5-\mathrm{x}} \mathrm{AB}_{2}$-type metal hydride alloys for electrochemical storage application: Part 2. Hydrogen storage and electrochemical properties. J. Power Sources 2012, 218, 487-494. [CrossRef]

120. Ji, S.; Li, S.; Sun, J. Effect of alloys with Mn, V on phase structures and electrochemical properties of $\mathrm{Zr}-\mathrm{Cr}-\mathrm{Ni}$ based $\mathrm{AB}_{2}$ hydrogen storage electrode alloys. Chin. J. Rare Met. 2004, 28, 657-661. (In Chinese)

121. Nei, J.; Young, K.; Regmi, R.; Lawes, G.; Salley, S.O.; Ng, K.Y.S. Gaseous phase hydrogen storage and electrochemical properties of $\mathrm{Zr}_{8} \mathrm{Ni}_{21}, \mathrm{Zr}_{7} \mathrm{Ni}_{10}, \mathrm{Zr}_{9} \mathrm{Ni}_{11}$, and $\mathrm{ZrNi}$ metal hydride alloys. Int. J. Hydrogen Energy 2012, 37, 16042-16055. [CrossRef]

122. Matsuyama, A.; Mizutani, H.; Kozuka, T.; Inoue, H. Effect of Ti substitution on electrochemical properties of $\mathrm{ZrNi}$ alloy electrode for use in nickel-metal hydride batteries. Int. J. Hydrogen Energy 2017. [CrossRef]

123. Matsuyama, A.; Mizutani, H.; Kozuka, T.; Inoue, H. Crystal structure and hydrogen absorption-desorption properties of $\mathrm{Zr}_{1-\mathrm{x}} \mathrm{Ti}_{\mathrm{x}} \mathrm{Ni}(0.05 \leq \mathrm{x} \leq 0.5)$ alloys. J. Alloys Compd. 2017, 714, 467-475. [CrossRef]

124. Ruiz, F.C.; Castro, E.B.; Real, S.G.; Peretti, H.A.; Visintin, A.; Triaca, W.E. Electrochemical characterization of $\mathrm{AB}_{2}$ alloys used for negative electrodes in Ni/MH batteries. Int. J. Hydrogen Energy 2008, 33, 3576-3580. [CrossRef]

125. Ruiz, F.C.; Castro, E.B.; Peretti, H.A.; Visintin, A. Study of the different $Z_{x} \mathrm{Ni}_{y}$ phases of $Z$ r-based $\mathrm{AB}_{2}$ materials. Int. J. Hydrogen Energy 2010, 35, 9879-9887. [CrossRef]

126. Young, K.; Ouchi, T.; Liu, Y.; Reichman, B.; Mays, W.; Fetcenko, M.A. Structural and electrochemical properties of $\mathrm{Ti}_{x} \mathrm{Zr}_{7-x} \mathrm{Ni}_{10}$. J. Alloys Compd. 2009, 480, 521-528. [CrossRef]

127. Young, K.; Ouchi, T.; Fetcenko, M.A.; Mays, W.; Reichman, B. Structural and electrochemical properties of $\mathrm{Ti}_{1.5} \mathrm{Zr}_{5.5} \mathrm{~V}_{x} \mathrm{Ni}_{10-x}$. Int. J. Hydrogen Energy 2009, 34, 8695-8706. [CrossRef]

128. Nei, J.; Young, K.; Salley, S.O.; Ng, K.Y.S. Effects of annealing on $\mathrm{Zr}_{8} \mathrm{Ni}_{19} \mathrm{X}_{2}$ (X= Ni, Mg, Al, Sc, V, Mn, Co, Sn, $\mathrm{La}$, and Hf): Hydrogen storage and electrochemical properties. Int. J. Hydrogen Energy 2012, 37, 8418-8427. [CrossRef]

129. Young, M.; Chang, S.; Young, K.; Nei, J. Hydrogen storage properties of $\mathrm{ZrV}_{x} \mathrm{Ni}_{3.5-x}(x=0.0-0.9)$ metal hydride alloys. J. Alloys Compd. 2013, 580, S171-S174. [CrossRef]

130. Young, K.; Young, M.; Chang, S.; Huang, B. Synergetic effects in electrochemical properties of $\mathrm{ZrV}_{x} \mathrm{Ni}_{4.5-x}$ $(x=0.0,0.1,0.2,0.3,0.4$, and 0.5) metal hydride alloys. J. Alloys Compd. 2013, 560, 33-41. [CrossRef] 
131. Zhu, Y.F.; Pan, H.G.; Wang, G.Y.; Gao, M.X.; Ma, J.X.; Chen, C.P.; Wang, Q.D. Phase structure, crystallography and electrochemical properties of Laves phase compounds $\mathrm{Ti}_{0.8} \mathrm{Zr}_{0.2} \mathrm{~V}_{1.6} \mathrm{Mn}_{0.8}{ }_{-x} \mathrm{M}_{x} \mathrm{Ni}_{0.6}(\mathrm{M}=\mathrm{Fe}, \mathrm{Al}, \mathrm{Cr}$, Co). Int. J. Hydrogen Energy 2001, 26, 807-816. [CrossRef]

132. Du, Y.L.; Yang, X.G.; Lei, Y.Q.; Zhang, M.S. Hydrogen storage properties of $\mathrm{Zr}_{0.8} \mathrm{Ti}_{0.2}\left(\mathrm{Ni}_{0.6} \mathrm{Mn}_{0.3-x} \mathrm{~V}_{0.1+x} \mathrm{Cr}_{0.05}\right)_{2}$ $(\mathrm{x}=0.0,0.05,0.15,0.2)$ alloys. Int. J. Hydrogen Energy 2002, 27, 695-697. [CrossRef]

133. Li, S.; Zhao, M.; Zhai, J.; Wang, F. Effect of substitution of chromium for nickel on structure and electrochemical characteristics of $\mathrm{Ti}_{0.26} \mathrm{Zr}_{0.07} \mathrm{~V}_{0.24} \mathrm{Mn}_{0.1} \mathrm{Ni}_{0.33}$ multi-phase hydrogen storage alloy. Mater. Chem. Phys. 2009, 113, 96-102.

134. Young, K.; Nei, J.; Wong, D.F.; Wang, L. Structural, hydrogen storage, and electrochemical properties of Laves phase-related body-centered-cubic solid solution metal hydride alloys. Int. J. Hydrogen Energy 2014, 39, 21489-21499. [CrossRef]

135. Young, K.; Ng, K.Y.S.; Bendersky, L.A. A technical report of the robust affordable next generation energy storage system-BASF program. Batteries 2016, 2, 2. [CrossRef]

136. Young, K.; Regmi, R.; Lawes, G.; Ouchi, T.; Reichman, B.; Fetcenko, M.A.; Wu, A. Effects of aluminum substitution in C14-rich multi-component alloys for NiMH battery application. J. Alloys Compd. 2010, 490, 282-292. [CrossRef]

137. Iba, H.; Akiba, E. The relation between microstructure and hydrogen absorbing property in Laves phase-solid solution multiphase alloys. J. Alloys Compd. 1995, 231, 508-512. [CrossRef]

138. Young, K.; Young, M.; Ouchi, T.; Reichman, B.; Fetcenko, M.A. Improvement in high-rate dischargeability, activation, and low-temperature performance in multi-phase $\mathrm{AB}_{2}$ alloys by partial substitution of $\mathrm{Zr}$ with $\mathrm{Y}$. J. Power Sources 2012, 215, 279-287. [CrossRef]

139. Young, K.; Wong, D.F.; Ouchi, T.; Huang, B.; Reichman, B. Effects of La-addition to the structure, hydrogen storage, and electrochemical properties of C14 metal hydride alloys. Electrochim. Acta 2015, 174, 815-825. [CrossRef]

140. Young, K.; Ouchi, T.; Nei, J.; Moghe, D. The importance of rare-earth additions in Zr-based $\mathrm{AB}_{2}$ metal hydride alloys. Batteries 2016, 2, 25. [CrossRef]

141. Wong, D.F.; Young, K.; Nei, J.; Wang, L.; Ng, K.Y.S. Effects of Nd-addition on the structural, hydrogen storage, and electrochemical properties of C14 metal hydride alloys. J. Alloys Compd. 2015, 647, 507-518. [CrossRef]

142. Yoshida, M.; Ishibashi, H.; Susa, K.; Ogura, T.; Akiba, E. The multiphase effect on crystal structure, hydrogen absorbing properties and electrode performance of Sc-Zr based Laves phase alloys. J. Alloys Compd. 1995, 230, 100-108. [CrossRef]

143. Chang, S.; Young, K.; Ouchi, T.; Meng, T.; Nei, J.; Wu, X. Studies on incorporation of Mg in Zr-based $\mathrm{AB}_{2}$ metal hydride alloys. Batteries 2016, 2, 11. [CrossRef]

144. Young, K.; Ouchi, T.; Huang, B.; Fetcenko, M.A. Effects of B, Fe, Gd, Mg, and C on the structure, hydrogen storage, and electrochemical properties of vanadium-free $\mathrm{AB}_{2}$ metal hydride alloy. J. Alloys Compd. 2012, 511, 242-250. [CrossRef]

145. Liu, H.; Li, R. Effect of Sn content on properties of $\mathrm{AB}_{2}$ hydrogen storage alloy. Foundry Technol. 2006, 27, 503-505. (In Chinese)

146. Pottgen, R.; Dronskowski, R. Structure and properties of $\mathrm{Zr}_{2} \mathrm{Ni}_{2} \mathrm{In}$ and $\mathrm{Zr}_{2} \mathrm{Ni}_{2}$ Sn. J. Solid State Chem. 1997, 128, 289-294. [CrossRef]

147. Pearson, W.B. The Crystal Chemistry and Physics of Metals and Alloys; Wiley-Interscience: New York, NY, USA, 1972; p. 59.

148. Nihon, K.G. Hi Kagaku Ryouronteki Kinzokukan Kagoubutsu; Maruzen: Tokyo, Japan, 1975; p. 296. (In Japanese)

149. Yukawa, H.; Nakatsuka, K.; Morinaga, M. Design of hydrogen storage alloys in view of chemical bond between atoms. Sol. Energy Mater. Sol. Cells 2000, 62, 75-80. [CrossRef]

150. Liu, S.; Sun, D. The current research and the development trend of hydrogen storage alloy. Rare Met. Cem. Carbides 2005, 33, 46-51. (In Chinese)

151. Kim, D.M.; Jeon, S.W.; Lee, J.Y. A study of the development of a high capacity and high performance $\mathrm{Zr}-\mathrm{Ti}-\mathrm{Mn}-\mathrm{V}-\mathrm{Ni}$ hydrogen storage alloy for Ni-MH rechargeable batteries. J. Alloys Compd. 1998, 279, 209-214. [CrossRef]

152. Kim, S.R.; Lee, J.Y.; Park, H.H. A study of the activation behaviour of Zr-Cr-Ni-La metal hydride electrodes in alkaline solution. J. Alloys Compd. 1994, 205, 225-229. [CrossRef] 
153. Shu, K.; Zhang, S.; Lei, Y.; Lü, G.; Wang, Q. Effect of Ti on the structure and electrochemical performance of Zr-based $\mathrm{AB}_{2}$ alloys for nickel-metal rechargeable batteries. J. Alloys Compd. 2003, 349, 237-241. [CrossRef]

154. Lee, H.H.; Lee, K.Y.; Lee, J.Y. Degradation mechanism of Ti-Zr-V-Mn-Ni metal hydride electrodes. J. Alloys Compd. 1997, 260, 201-207. [CrossRef]

155. Züttel, A.; Meli, F.; Schlapbach, L. Surface and bulk properties of the $\mathrm{Ti}_{y} \mathrm{Zr}_{1-y}\left(\mathrm{~V}_{x} \mathrm{Ni}_{1-x}\right)_{2}$ alloy system as active electrode material in alkaline electrolyte. J. Alloys Compd. 1995, 231, 645-649. [CrossRef]

156. Visintin, A.; Peretti, H.A.; Tori, C.A.; Triaca, W.E. Hydrogen absorption characteristics and electrochemical properties of Ti substituted $\mathrm{Zr}$-based $\mathrm{AB}_{2}$ alloys. Int. J. Hydrogen Energy 2001, 26, 683-689. [CrossRef]

157. Sun, J.C.; Li, S.; Ji, S.J. Phase composition and electrochemical performances of the $Z_{1-x} \mathrm{Ti}_{x} \mathrm{Cr}_{0.4} \mathrm{Mn}_{0.2}$ $\mathrm{V}_{0.1} \mathrm{Ni}_{1.3}$ alloys with $0.1 \leq \mathrm{x} \leq 0.3$. J. Alloys Compd. 2005, 404, 687-690. [CrossRef]

158. Zhu, Y.F.; Pan, H.G.; Gao, M.X.; Ma, J.X.; Li, S.Q.; Wang, Q.D. The effect of Zr substitution for Ti on the microstructures and electrochemical properties of electrode alloys $\mathrm{Ti}_{1-x} \mathrm{Zr}_{x} \mathrm{~V}_{1.6} \mathrm{Mn}_{0.32} \mathrm{Cr}_{0.48} \mathrm{Ni}_{0.6}$. Int. J. Hydrogen Energy 2002, 27, 287-293. [CrossRef]

159. Hariprakash, B.; Martha, S.K.; Shukla, A.K. Effect of copper additive on $\mathrm{Zr}_{0.9} \mathrm{Ti}_{0.1} \mathrm{~V}_{0.2} \mathrm{Mn}_{0.6} \mathrm{Cr}_{0.05} \mathrm{Co}_{0.05} \mathrm{Ni}_{1.2}$ alloy anode for nickel-metal hydride batteries. J. Appl. Electrochem. 2003, 33, 497-504. [CrossRef]

160. Huot, J.; Akiba, E.; Ogura, T.; Ishido, Y. Crystal structure, phase abundance and electrode performance of Laves phase compounds ( $\mathrm{Zr}, \mathrm{A}) \mathrm{V}_{0.5} \mathrm{Ni}_{1.1} \mathrm{Mn}_{0.2} \mathrm{Fe}_{0.2}$ ( $\mathrm{A} \equiv \mathrm{Ti}$, Nb or Hf). J. Alloys Compd. 1995, 218, 101-109. [CrossRef]

161. Huot, J.; Akiba, E.; Ishido, Y. Crystal structure of multiphase alloys (Zr,Ti)(Mn,V)2. J. Alloys Compd. 1995, 231, 85-89. [CrossRef]

162. Nei, J.; Young, K.; Salley, S.O.; Ng, K.Y.S. Determination of C14/C15 phase abundance in Laves phase alloys. Mater. Chem. Phys. 2012, 136, 520-527. [CrossRef]

163. Kandavel, M.; Bhat, V.V.; Rougier, A.; Aymard, L.; Nazri, G.A.; Tarascon, J.M. Improvement of hydrogen storage properties of the $\mathrm{AB}_{2}$ Laves phase alloys for automotive application. Int. J. Hydrogen Energy 2008, 33, 3754-3761. [CrossRef]

164. Wakao, S.; Sawa, H.; Furukawa, J. Effects of partial substitution and anodic oxidation treatment of Zr-V-Ni alloys on electrochemical properties. J. Less Common Met. 1991, 172, 1219-1226. [CrossRef]

165. Kim, S.; Lee, J. Activation behaviour of $\mathrm{ZrCrNiM}_{0.05}$ metal hydride electrode $(\mathrm{M}=\mathrm{La}$, Mm (misch metal), Nd). J. Alloys Compd. 1992, 185, L1-L4. [CrossRef]

166. Rönnebro, E.; Noréus, D.; Sakai, T.; Tsukahara, M. Structural studies of a new Laves phase alloy $(\mathrm{Hf}, \mathrm{Ti})(\mathrm{Ni}, \mathrm{V})_{2}$ and its very stable hydride. J. Alloys Compd. 1995, 231, 90-94. [CrossRef]

167. Huot, J.; Akiba, E.; Orura, O.; Ishido, Y. Crystal structure of electrode materials ( $\mathrm{Zr}, \mathrm{A}) \mathrm{V}_{0.5} \mathrm{Ni}_{1.1} \mathrm{Mn}_{0.2} \mathrm{Fe}_{0.2}$ $(\mathrm{A}=\mathrm{Ti}, \mathrm{Nb}$ and $\mathrm{Hf})$ for Ni-hydrogen rechargeable batteries. Trans. Mater. Res. Soc. Jpn. 1994, 18B, 1197-1200.

168. Zhou, O.; Yao, Q.; Sun, X.; Gu, Q.; Sun, J. Lattice-substitution of alloying elements and its influences on mechanical properties of $\mathrm{ZrCr}_{2}$ Laves phase. Chin. J. Nonferr. Met. 2006, 16, 1603-1607. (In Chinese)

169. Santos, A.R.; Ambrosio, R.C.; Ticianelli, E.A. Electrochemical and structural studies on nonstoichiometric $\mathrm{AB}_{2}$-type metal hydride alloys. Int. J. Hydrogen Energy 2004, 29, 1253-1261.

170. Young, K.; Ouchi, T.; Nei, J.; Chang, S. Increase in the Surface Catalytic Ability by Addition of Palladium in C14 Metal Hydride Alloy. Batteries 2017, 3, 26. [CrossRef]

171. Yang, X.G.; Zhang, W.K.; Lei, Y.Q.; Wang, Q.D. Electrochemical properties of Zr-V-Ni system hydrogen storage alloys. J. Electrochem. Soc. 1999, 146, 1245-1250. [CrossRef]

172. Ovshinsky, S.R.; Young, R. High Power Nickel-Metal Hydride Batteries and High Power Alloys/Electrodes for Use Therein. U.S. Patent 6,413,670 B1, 2 July 2002.

173. Yoshida, M.; Akiba, E. Hydrogen absorbing properties of $\mathrm{ScM}_{2}$ Laves phase alloys $(\mathrm{M}=\mathrm{Fe}, \mathrm{Co}$ and $\mathrm{Ni})$. J. Alloys Compd. 1995, 226, 75-80. [CrossRef]

174. Yoshida, M.; Ishibashi, H.; Susa, K.; Ogura, T.; Akiba, E. Crystal structure, hydrogen absorbing properties and electrode performances of Sc-based Laves phase alloys. J. Alloys Compd. 1995, 226, 161-165. [CrossRef]

175. Li, K.; Luo, Y.; Wang, W.; Qiu, J.; Kang, L. Effects of scandium on hydrogen storage and electrochemical properties of $\mathrm{AB}_{2}$-type $\mathrm{Zr}_{1-x} \mathrm{Sc}_{x} \mathrm{Mn}_{0.6} \mathrm{~V}_{0.2} \mathrm{Ni}_{1.2} \mathrm{Co}_{0.1}(x=0 \sim 1)$ alloys. J. Chin. Rare Earth Soc. 2013, 31, 442-449. (In Chinese)

176. Liu, X.J.; Yang, S.Y.; Huang, Y.X.; Zhang, J.B.; Wang, C.P. Experimental investigation of isothermal sections $\left(100,1200{ }^{\circ} \mathrm{C}\right)$ in the Ni-Ti-Zr system. J. Ph. Equilib. Diffus. 2015, 36, 414-421. [CrossRef] 
177. Young, K.; Fetcenko, M.A.; Li, F.; Ouchi, T.; Koch, J. Effect of vanadium substitution in C14 Laves phase alloys for NiMH battery application. J. Alloys Compd. 2009, 468, 482-492. [CrossRef]

178. Young, K.; Ouchi, T.; Koch, J.; Fetcenko, M.A. Compositional optimization of vanadium-free hypo-stoichiometric $\mathrm{AB}_{2}$ metal hydride alloy for $\mathrm{Ni} / \mathrm{MH}$ battery application. J. Alloys Compd. 2012, 510, 97-106. [CrossRef]

179. Wang, J.; Yu, R.; Liu, Q. Relation of element substitution to discharge capacity and activation of Ti-Zr based $\mathrm{AB}_{2}$-type hydrogen storage electrode alloys. Mater. Sci. Technol. 2005, 13, 166-170. (In Chinese)

180. Yang, H.W.; Wang, Y.Y.; Wan, C.C. Studies of electrochemical properties of $\mathrm{Ti}_{0.35} \mathrm{Zr}_{0.65} \mathrm{Ni}_{x} \mathrm{~V}_{2-x-y} \mathrm{Mn}_{y}$ alloys with C14 Laves phases for nickel/metal hydride batteries. J. Electrochem. Soc. 1996, 143, 429-435. [CrossRef]

181. Hagström, M.T.; Klyamkin, S.N.; Lund, P.D. Effect of substitution on hysteresis in some high-pressure $\mathrm{AB}_{2}$ and $\mathrm{AB}_{5}$ metal hydrides. J. Alloys Compd. 1999, 293, 67-73. [CrossRef]

182. Lee, S.F.; Wang, Y.Y.; Wan, C.C. Effect of adding chromium to Ti-Zr-Ni-V-Mn alloy on its cycle life as an $\mathrm{Ni}$ /metal-hydride battery material. J. Power Sources 1997, 66, 165-168. [CrossRef]

183. Lee, H.; Lee, S.; Lee, J. Activation characteristics of multiphase Zr-based hydrogen storage alloys for $\mathrm{Ni} / \mathrm{MH}$ rechargeable batteries. J. Electrochem. Soc. 1999, 146, 3666-3671. [CrossRef]

184. Park, H.Y.; Chang, I.; Cho, W.I.; Cho, B.W.; Jang, H.; Lee, S.R.; Yun, K.S. Electrode characteristics of the Cr and La doped $\mathrm{AB}_{2}$-type hydrogen storage alloys. Int. J. Hydrogen Energy 2001, 26, 949-955. [CrossRef]

185. Liu, B.H.; Li, Z.P.; Kitani, R.; Suda, S. Improvement of electrochemical cyclic durability of Zr-based $\mathrm{AB}_{2}$ alloy electrodes. J. Alloys Compd. 2002, 330, 825-830. [CrossRef]

186. Young, K.; Ouchi, T.; Fetcenko, M.A. Roles of Ni, Cr, Mn, Sn, Co, and Al in C14 Laves phase alloys for NiMH battery application. J. Alloys Compd. 2009, 476, 774-781. [CrossRef]

187. Peretti, H.A.; Visintin, A.; Mogni, L.V.; Corso, H.L.; Gamboa, J.A.; Serafini, D.; Triaca, W.E. Hydrogen absorption behavior of multicomponent zirconium based $\mathrm{AB}_{2}$ alloys with different chromium-vanadium ratio. J. Alloys Compd. 2003, 354, 181-186. [CrossRef]

188. Wang, G.Y.; Xu, Y.H.; Pan, H.G.; Wang, Q.D. Effect of substitution of chromium for manganese on structure discharge characteristics of Ti-Zr-V-Mn-Ni-type multi-phase hydrogen storage electrode alloys. Int. J. Hydrogen Energy 2003, 28, 499-508. [CrossRef]

189. Pan, H.; Li, R.; Gao, M.; Liu, Y.; Wang, Q. Effects of Cr on the structural and electrochemical properties of TiV-based two-phase hydrogen storage alloys. J. Alloys Compd. 2005, 404, 669-674. [CrossRef]

190. Yu, J.; Lee, S.; Cho, K.; Lee, J. The cycle life of $\mathrm{Ti}_{0.8} \mathrm{Zr}_{0.2} \mathrm{~V}_{0.5} \mathrm{Mn}_{0.5-\mathrm{x}} \mathrm{Cr}_{x} \mathrm{Ni}_{0.8}(x=0$ to 0.5) alloys for metal hydride electrodes of Ni-metal hydride rechargeable battery. J. Electrochem. Soc. 2000, 147, 2013-2017. [CrossRef]

191. Xu, Y.H.; Chen, C.P.; Wang, X.L.; Lei, Y.Q.; Wang, Q.D. The cycle life and surface properties of Ti-based $\mathrm{AB}_{2}$ metal hydride electrodes. J. Alloys Compd. 2002, 337, 214-220. [CrossRef]

192. Shinyama, K.; Magari, Y.; Akita, H.; Kumagae, K.; Nakamura, H.; Matsuta, S.; Nohma, T.; Takee, M.; Ishiwa, K. Investigation into the deterioration in storage characteristics of nickel-metal hydride batteries during cycling. J. Power Sources 2005, 143, 265-269. [CrossRef]

193. Chen, J.; Dou, S.X.; Liu, H.K. Hydrogen desorption and electrode properties of $\mathrm{Zr}_{0.8} \mathrm{Ti}_{0.2}\left(\mathrm{~V}_{0.3} \mathrm{Ni}_{0.6} \mathrm{M}_{0.1}\right)_{2}$. J. Alloys Compd. 1997, 256, 40-44. [CrossRef]

194. Chai, Y.J.; Zhao, M.S.; Wang, N. Crystal structural and electrochemical properties of $\mathrm{Ti}_{0.17} \mathrm{Zr}_{0.08} \mathrm{~V}_{0.35} \mathrm{Cr}_{0.10}$ $\mathrm{Ni}_{0.30-x} \mathrm{Mn}_{x}(x=0-0.12)$ alloys. Mater. Sci. Eng. B 2008, 147, 47-51. [CrossRef]

195. Young, K.; Ouchi, T.; Huang, B.; Reichman, B.; Fetcenko, M.A. The structure, hydrogen storage, and electrochemical properties of Fe-doped C14-predominating $\mathrm{AB}_{2}$ metal hydride alloys. Int. J. Hydrogen Energy 2011, 36, 12296-12304. [CrossRef]

196. Song, M.Y.; Ahn, D.; Kwon, I.; Lee, R.; Rim, H. Development of $\mathrm{AB}_{2}$-type Zr-Ti-Mn-V-Ni-Fe hydride electrodes for Ni-MH secondary batteries. J. Alloys Compd. 2000, 298, 254-260. [CrossRef]

197. Song, M.Y.; Kown, I.H.; Ahh, D.S.; Sohn, M.S. Improvement in the electrochemical properties of $\mathrm{ZrMn}_{2}$ hydrides by substitution of elements. Met. Mater. Int. 2001, 7, 257-263. [CrossRef]

198. Kim, S.R.; Lee, J.Y. Electrode characteristics of C14-type Zr-based laves phase alloys. J. Alloys Compd. 1994, 210, 109-113. [CrossRef]

199. Song, M.Y.; Ahn, D.; Kwon, I.H.; Chough, S.H. Development of AB 2 -type Zr-Ti-Mn-V-Ni-M hydride electrode for Ni/MH secondary battery. J. Electrochem. Soc. 2001, 148, A1041-A1044. [CrossRef] 
200. Honda, N.; Furukawa, N.; Fujitani, S.; Yonezu, I. Hydrogen Absorbing Modified ZrMn 2 -Type Alloys. U.S. Patent 4,913,879, 3 April 1990.

201. Ovshinsky, S.R.; Fetcenko, M.A.; Ross, J. A nickel metal hydride battery for electric vehicles. Science 1993, 260, 176-181. [CrossRef] [PubMed]

202. Kim, S.R.; Lee, K.Y.; Lee, J.Y. Improved low-temperature dischargeability of C14-type Zr-Cr-Ni Laves phase alloy. J. Alloys Compd. 1995, 223, 22-27. [CrossRef]

203. Kwon, I.; Park, H.; Song, M. Electrochemical properties of $\mathrm{ZrMnNi}_{1+x}$ hydrogen-storage alloys. Int. J. Hydrogen Energy 2002, 27, 171-176. [CrossRef]

204. Lee, H.H.; Lee, K.Y.; Lee, J.Y. The Ti-based metal hydride electrode for NiMH rechargeable batteries. J. Alloys Compd. 1996, 239, 63-70. [CrossRef]

205. Young, K.; Ouchi, T.; Huang, B.; Reichman, B.; Fetcenko, M.A. Studies of copper as a modifier in C14-predominant $\mathrm{AB}_{2}$ metal hydride alloys. J. Power Sources 2012, 204, 205-212. [CrossRef]

206. Yamamura, Y.; Seri, H.; Tsuji, Y.; Owada, N.; Iwaki, T. Hydrogen Storage Alloy and Electrode Therefrom. U.S. Patent 5,532,076, 2 July 1996.

207. Young, K.; Ouchi, T.; Lin, X.; Reichman, B. Effects of Zn-addition to C14 metal hydride alloys and comparisons to $\mathrm{Si}, \mathrm{Fe}, \mathrm{Cu}, \mathrm{Y}$, and Mo-additives. J. Alloys Compd. 2016, 655, 50-59. [CrossRef]

208. Wang, Y.; Zhao, D.; Yuan, H.; Wang, G.; Zhou, Z.; Song, D.; Zhang, Y. Preparation and electrochemical properties of MI(NiCuAlZn) ${ }_{5}$ hydrogen storage alloys. Acta Sci. Bat. Univ. Nankaiensis 2000, 33, 120-123. (In Chinese)

209. Young, K.; Ouchi, T.; Huang, B.; Reichman, B.; Fetcenko, M.A. Effect of molybdenum content on structural, gaseous storage, and electrochemical properties of $\mathrm{C} 14$-predominant $\mathrm{AB}_{2}$ metal hydride alloys. J. Power Sources 2011, 196, 8815-8821. [CrossRef]

210. Au, M.; Pourarian, F.; Sankar, S.G.; Wallace, W.E.; Zhang, L. TiMn2-bases alloys as high hydrogen materials. Mater. Sci. Eng. B 1995, 33, 53-57. [CrossRef]

211. Huang, T.; Wu, Z.; Xia, B.; Xu, N. Influence of stoichiometry and alloying elements on the crystallography and hydrogen sorption properties of TiCr based alloys. Mater. Sci. Eng. A 2005, 397, 284-287.

212. Erika, T.; Ricardo, F.; Fabricio, R.; Fernando, Z.; Verónica, D. Electrochemical and metallurgical characterization of $\mathrm{ZrCr}_{1-x} \mathrm{NiMo}_{x} \mathrm{AB}_{2}$ metal hydride alloys. J. Alloys Compd. 2015, 649, 267-274. [CrossRef]

213. Doi, H.; Yabuki, R. Hydrogen Absorbing Ni, Zr-Based Alloy and Rechargeable Alkaline Battery. U.S. Patent 4,898,794, 6 February 1990.

214. Ruiz, F.C.; Peretti, H.A.; Visintin, A.; Triaca, W.E. A study on $\mathrm{ZrCrNiPt}_{\mathrm{x}}$ alloys as negative electrode components for NiMH batteries. Int. J. Hydrogen Energy 2011, 36, 901-906. [CrossRef]

215. Luan, B.; Cui, N.; Zhao, H.J.; Liu, H.K.; Dou, S.X. Effects of potassium-boron addition on the performance of titanium based hydrogen storage alloy electrodes. Int. J. Hydrogen Energy 1996, 21, 373-379. [CrossRef]

216. Reddy, A.L.M.; Ramaprabhu, S. Hydrogen diffusion studied in Zr-based Laves phase $\mathrm{AB}_{2}$ alloys. J. Alloys Compd. 2008, 460, 268-271. [CrossRef]

217. Reddy, A.L.M.; Ramaprabhu, S. Structural and hydrogen absorption kinetics studies of polymer dispersed and boron added $\mathrm{Zr-based} \mathrm{AB}_{2}$ alloy. Int. J. Hydrogen Energy 2006, 31, 867-876.

218. Li, S.; Wen, B.; Li, X. Structure and electrochemical property of ball-milled $\mathrm{Ti}_{0.26} \mathrm{Zr}_{0.07} \mathrm{Mn}_{0.1} \mathrm{Ni}_{0.33} \mathrm{~V}_{0.24}$ alloy with 3 mass\% B. J. Alloys Compd. 2016, 654, 580-585. [CrossRef]

219. Young, K.; Fetcenko, M.A.; Koch, J.; Morii, K.; Shimizu, T. Studies of Sn, Co, Al, and Fe additives in C14/C15 Laves alloys for NiMH battery application by orthogonal arrays. J. Alloys Compd. 2009, 486, 559-569. [CrossRef]

220. Fetcenko, M.A.; Young, K.; Ovshinky, S.R.; Reichman, B.; Koch, J.; Mays, W. Modified Electrochemical Hydrogen Storage Alloy Having Increased Capacity, Rate Capability and Catalytic Activity. U.S. Patent 6,270,719, 7 August 2001.

221. Gamo, T.; Moriwaki, Y.; Iwaki, T. Alloy for Hydrogen Storage Electrodes. U.S. Patent 4,946,646, 7 August 1990.

222. Doi, H.; Yabuki, R. Hydrogen Absorbing Ni-Based Alloy and Rechargeable Alkaline Battery. U.S. Patent 4,983,474, 9 January 1991.

223. Yu, X.B.; Wu, Z.; Huang, T.Z.; Chen, J.Z.; Xia, B.J.; Xu, N.X. Effect of carbon addition on activation and hydrogen sorption characteristics of $\mathrm{TiMn}_{1.25} \mathrm{Cr}_{0.25}$ alloy. Mater. Chem. Phys. 2004, 83, 273-277. [CrossRef]

224. Young, K.; Ouchi, T.; Huang, B.; Reichman, B.; Blankenship, R. Improvement in $-40{ }^{\circ} \mathrm{C}$ electrochemical properties of $\mathrm{AB}_{2}$ metal hydride alloy by silicon incorporation. J. Alloys Compd. 2013, 575, 65-72. [CrossRef] 
225. Han, S.; Zhoa, M.; Liu, B. Microstructure and high-temperature electrochemical characteristics of $\mathrm{Zr}_{0.9} \mathrm{Ti}_{0.1} \mathrm{Ni}_{1.0} \mathrm{Mn}_{0.7} \mathrm{~V}_{0.3} \mathrm{Si}_{x}(x=0.05,0.10,0.15,0.20)$ alloy. Mater. Chem. Phys. 2005, 89, 221-227. [CrossRef]

226. Li, S.; Liu, Y.; Zhu, J. Effect of Si-element on electrochemical properties of Ti-based hydrogen storage alloys. Titan. Ind. Prog. 2007, 24, 10-22. (In Chinese)

227. Young, K.; Chao, B.; Nei, J. Microstructures of the activated Si-containing $\mathrm{AB}_{2}$ metal hydride alloy surface by transmission electron microscope. Batteries 2016, 2, 4. [CrossRef]

228. Drašner, A.; Blažina, $\hat{Z}$. The influence of $\mathrm{Si}$ and Ge on the hydrogen sorption properties of the intermetallic compound $\mathrm{ZrCr}_{2}$. J. Alloys Compd. 1993, 199, 101-104.

229. Xu, L.; Xiao, Y.; Sandwijk, A.; Xu, Q.; Yang, Y. Separation of zirconium and hafnium: A review. In Energy Materials 2014; Springer: Heidelberg, Germany, 2014; p. 451.

230. Yamanaka, S.; Higuchi, K.; Miyake, M. Hydrogen solubility in zirconium alloys. J. Alloys Compd. 1995, 231, 503-507. [CrossRef]

231. Young, K.; Fetcenko, M.A.; Ouchi, T.; Li, F.; Koch, J. Effect of Sn-substitution in C14 Laves phase alloys for NiMH battery application. J. Alloys Compd. 2009, 469, 406-416. [CrossRef]

232. Morita, Y.; Gamo, T.; Kuranaka, S. Effects of nonmetal addition on hydriding properties for Ti-Mn Laves phase alloys. J. Alloys Compd. 1997, 253, 29-33. [CrossRef]

233. Giza, K.; Isasieczko, W.; Pavlyuk, V.V.; Bala, H.; Drulis, H.; Adamczyk, L. Hydrogen absorption and corrosion resistance of $\mathrm{LaNi}_{4.8} \mathrm{Al}_{0.2}$ and $\mathrm{LaNi}_{4.8} \mathrm{Al}_{0.1} \mathrm{Li}_{0.1}$ alloy. J. Alloys Compd. 2007, 429, 352-356. [CrossRef]

234. Wei, X.; Tang, R.; Liu, Y.; Zhang, P.; Yu, G.; Zhu, J. Effect of small amounts of Li on microstructures and electrochemical properties of non-stoichiometric low-Co $\mathrm{AB}_{5}$-type alloys. Int. J. Hydrogen Energy 2006, 31, 1365-1371. [CrossRef]

235. Wang, L.; Yuan, H.; Yang, H.; Zhou, K.; Song, D.; Zhang, Y. Study of the multi-composition $\mathrm{AB}_{2}$ alloys including Li, made by the diffusion method, and their electrodes. J. Alloys Compd. 2000, 302, 65-69. [CrossRef]

236. Cracco, D.; Percheron-Guégan, A. Morphology and hydrogen absorption properties of an $\mathrm{AB}_{2}$ type alloy ball milled with $\mathrm{Mg}_{2} \mathrm{Ni}$. J. Alloys Compd. 1998, 268, 248-255. [CrossRef]

237. Wang, Y.; Zhao, M. Electrochemical hydrogen storage characteristics of $\mathrm{Ti}_{0.10} \mathrm{Zr}_{0.15} \mathrm{~V}_{0.35} \mathrm{Cr}_{0.10} \mathrm{Ni}_{0.30}-10 \%$ $\mathrm{LaNi}_{3}$ composite and its synergetic effect. Trans. Nonferr. Met. Soc. China 2012, 22, 2000. (In Chinese) [CrossRef]

238. Chu, H.; Zhang, Y.; Sun, L.; Qiu, S.; Xu, F.; Yuan, H.; Wang, Q.; Dong, C. Structure, morphology and hydrogen storage properties of composites prepared by ball milling $\mathrm{Ti}_{0.9} \mathrm{Zr}_{0.2} \mathrm{Mn}_{1.5} \mathrm{Cr}_{0.3} \mathrm{~V}_{0.3}$ with La-Mg-based alloy. Int. J. Hydrogen Energy 2007, 32, 3363-3369. [CrossRef]

239. Liu, F.J.; Sandrock, G.; Suda, S. Surface and metallographic microstructure of the La-added $\mathrm{AB}_{2}$ compound (Ti, Zr)(Mn, Cr, Ni) 2 . J. Alloys Compd. 1995, 231, 392-396. [CrossRef]

240. Sun, D.; Latroche, M.; Percheron-Guégan, A. Effects of lanthanum or cerium on the equilibrium of $\mathrm{ZrNi}_{1.2} \mathrm{Mn}_{0.6} \mathrm{~V}_{0.2} \mathrm{Cr}_{0.1}$ and its related hydrogenation properties. J. Alloys Compd. 1997, 248, 215-219. [CrossRef]

241. Yang, X.G.; Lei, Y.Q.; Shu, K.Y.; Lin, G.F.; Zhang, Q.A.; Zhang, W.K.; Zhang, X.B.; Lu, G.L.; Wang, Q.D. Contribution of rare-earths to activation property of Zr-based hydride electrode. J. Alloys Compd. 1999, 293, 632-636. [CrossRef]

242. Sun, J.C.; Li, S.; Ji, S.J. The effects of the substitution of Ti and $\mathrm{La}$ for $\mathrm{Zr}$ in $\mathrm{ZrMn}_{0.7} \mathrm{~V}_{0.2} \mathrm{Co}_{0.1} \mathrm{Ni}_{1.2}$ hydrogen storage alloys on the phase structure and electrochemical properties. J. Alloys Compd. 2007, 446, 630-634. [CrossRef]

243. Chen, W.X. Effects of addition of rare-earth element on electrochemical characteristics of $\mathrm{ZrNi}_{1.1} \mathrm{Mn}_{0.5} \mathrm{~V}_{0.3} \mathrm{Cr}_{0.1}$ hydrogen storage alloy electrodes. J. Alloys Compd. 2001, 319, 119-123. [CrossRef]

244. Jung, J.H.; Lee, K.Y.; Lee, J.Y. The activation mechanism of Zr-based alloy electrodes. J. Alloys Compd. 1995, 226, 166-169. [CrossRef]

245. Joubert, J.M.; Sun, D.; Latroche, M.; Percheron-Guegan, A. Electrochemical performances of $\mathrm{ZrM} 2(\mathrm{M}=\mathrm{V}, \mathrm{Cr}$, $\mathrm{Mn}, \mathrm{Ni}$ ) Laves phases and the relation to microstructures and thermodynamical properties. J. Alloys Compd. 1997, 253, 564-569. [CrossRef]

246. Han, S.M.; Zhang, Z.; Zhao, M.S.; Zheng, Y.Z. Electrochemical characteristics and microstructure of $\mathrm{Zr}_{0.9} \mathrm{Ti}_{0.1} \mathrm{Ni}_{1.1} \mathrm{Mn}_{0.6} \mathrm{~V}_{0.3}-\mathrm{LaNi}_{5}$ composite hydrogen storage alloys. Int. J. Hydrogen Energy 2006, 31, 563-567. [CrossRef] 
247. Wang, Y.; Zhao, M.; Li, S.; Wang, L. Structure and electrochemical characteristics of melted composite $\mathrm{Ti}_{0.10} \mathrm{Zr}_{0.15} \mathrm{~V}_{0.35} \mathrm{Cr}_{0.10} \mathrm{Ni}_{0.30}-\mathrm{LaNi}_{5}$ hydrogen storage alloys. Electrochim. Acta 2008, 53, 7831-7837. [CrossRef]

248. Lu, Z.; Qin, M.; Jiang, W.; Qing, P.; Liu, S. Effect of $\mathrm{AB}_{2}$-based alloy addition on structure and electrochemical properties of $\mathrm{La}_{0.5} \mathrm{Pr}_{0.2} \mathrm{Zr}_{0.1} \mathrm{Mg}_{0.2} \mathrm{Ni}_{2.75} \mathrm{Co}_{0.45} \mathrm{Fe}_{0.1} \mathrm{Al}_{0.2}$ hydrogen storage alloy. J. Rare Earths 2013, 31, 386-394. [CrossRef]

249. HEFA Rare Earth. Available online: http:/ / mineralprices.com (accessed on 8 May 2017).

250. Griessen, R.; Riesterer, T. Heat of Formation Models. In Hydrogen in Intermetallic Compounds I; Schlapbach, L., Ed.; Springer: Berlin/Heidelberg, Germany, 1988.

251. Zhu, J.H.; Pike, L.M.; Liu, C.T.; Liaw, P.K. Point defects in Binary $\mathrm{NbCr}_{2}$ Laves-phase alloys. Scr. Mater. 1998, 39, 833-838. [CrossRef]

252. Kanazawa, S.; Kaneno, Y.; Inoue, H.; Kim, W.Y.; Takasugi, T. Microstructures and defect structures in $\mathrm{ZrCr}_{2}$ Laves phase based intermetallic compounds. Intermetallics 2002, 10, 783-792. [CrossRef]

253. Wong, D.F.; Young, K.; Ouchi, T.; Ng, K.Y.S. First-principles point defect models for $\mathrm{Zr}_{7} \mathrm{Ni}_{10}$ and $\mathrm{Zr}_{2} \mathrm{Ni}_{7}$ phases. Batteries 2016, 2, 23. [CrossRef]

254. Massalski, T.B. Binary Alloy Phase Diagrams, 2nd ed.; ASM International: Russell, OH, USA, 1990.

255. Notten, P.H.L.; Einerhand, R.E.F.; Daams, J.L.C. How to achieve long-term electrochemical cycling stability with hydride-forming electrode materials. J. Alloys Compd. 1995, 231, 604-610. [CrossRef]

256. Young, K.; Ouchi, T.; Yang, J.; Fetcenko, M.A. Studies of off-stoichiometric $\mathrm{AB}_{2}$ metal hydride alloy: Part 1. Structural characteristics. Int. J. Hydrogen Energy 2011, 36, 11137-11145. [CrossRef]

257. Young, K.; Nei, J.; Huang, B.; Fetcenko, M.A. Studies of off-stoichiometric $\mathrm{AB}_{2}$ metal hydride alloy: Part 2. Hydrogen storage and electrochemical properties. Int. J. Hydrogen Energy 2011, 36, 11146-11154. [CrossRef]

258. Liu, B.H.; Li, Z.P.; Suda, S. Electrochemical cycle life of Zr-based Laves phase alloys influenced by alloy stoichiometry and composition. J. Electrochem. Soc. 2002, 149, A537-A542. [CrossRef]

259. Zhu, Y.; Pan, H.; Gao, M.; Ma, J.; Lei, Y.; Wang, Q. Electrochemical studies on the Ti-Zr-V-Mn-Cr-Ni hydrogen storage electrode alloys. Int. J. Hydrogen Energy 2003, 28, 311-316. [CrossRef]

260. Pan, H.; Zhu, Y.; Gao, M.; Liu, Y.; Li, R.; Lei, Y.; Wang, Q. A study on the cycling stability of the Ti-V-based hydrogen storage electrode alloys. J. Alloys Compd. 2004, 364, 271-279. [CrossRef]

261. Yasuoka, S.; Magari, Y.; Murata, T.; Tanaka, T.; Ishida, J.; Nakamura, H.; Nohma, T.; Kihara, M.; Baba, Y.; Teraoka, H. Development of high-capacity nickel-metal hydride batteries using superlattice hydrogen-absorbing alloys. J. Power Sources 2006, 156, 662-666. [CrossRef]

262. Young, K.; Fetcenko, M.A. Low Cost, High Power, High Energy, Solid-State, Bipolar Metal Hydride Batteries. U.S. Patent 8,974,948, 10 March 2015.

263. Young, K.; Wong, D.; Nei, J.; Reichman, B.; Chao, B.; Mays, W. Shared Electrode Hybrid Battery-Fuel Cell System. U.S. Patent Appl. 20,150,295,290, 15 October 2015.

264. Zelinsky, M.A.; Koch, J.M. Nickel/metal hydride batteries in stationary applications. Batteries 2017, submitted.

265. Wikipedia. Start-Stop System. Available online: https://en.wikipedia.org/wiki/Start-stop_system (accessed on 31 July 2017).

266. Yan, S.; Meng, T.; Young, K.; Nei, J. Nickel/metal hydride battery in a pouch design. Batteries 2017, in preparation.

267. Young, K.; Nei, J.; Meng, T. Alkaline and Non-Aqueous Proton-Conducting Pouch-Cell Batteries. U.S. Patent Appl. 20,160,233,461, 11 August 2016.

268. Meng, T.; Young, K.; Wong, D.F.; Nei, J. Ionic liquid-based non-aqueous electrolytes for nickel/metal hydride batteries. Batteries 2017, 2, 4. [CrossRef]

(C) 2017 by the authors. Licensee MDPI, Basel, Switzerland. This article is an open access article distributed under the terms and conditions of the Creative Commons Attribution (CC BY) license (http:/ / creativecommons.org/licenses/by/4.0/). 